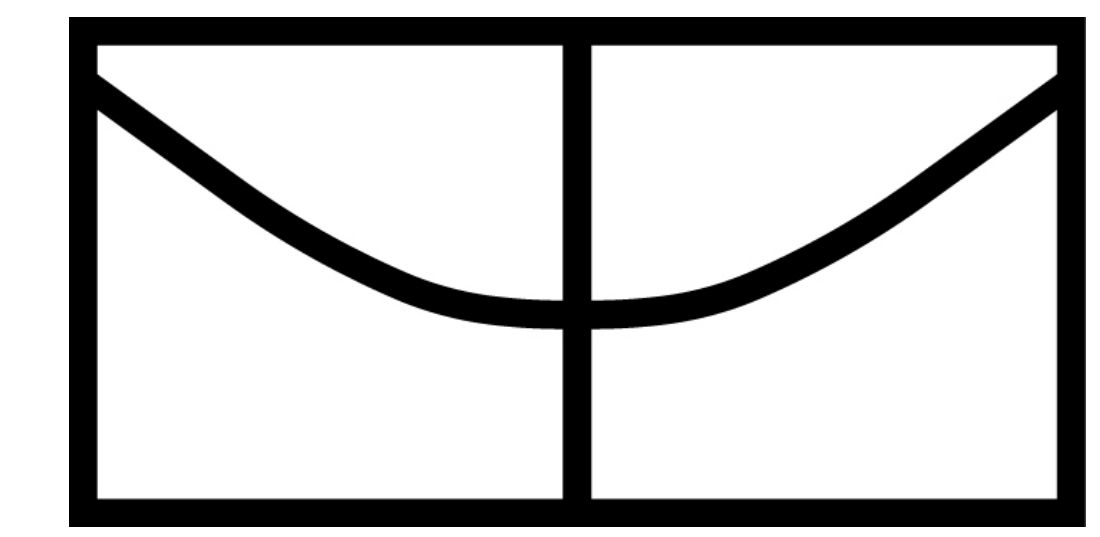

UNIVERSIDADE DE BRASÍLIA

FACULDADE DE COMUNICAÇÃO

DEPARTAMENTO DE COMUNICAÇÃO ORGANIZACIONAL

Emmeline de Santana Portela

EMBRIAGADO DE AMOR E SANGUE NEGRO: MANIFESTAÇÕES DE SILÊNCIO VERBAL E INCOMUNICAÇÃO NOS FILMES DE PAUL

THOMAS ANDERSON 

Emmeline de Santa Portela

EMBRIAGADO DE AMOR E SANGUE NEGRO: MANIFESTAÇÕES DE SILÊNCIO VERBAL E INCOMUNICAÇÃO NOS FILMES DE PAUL

THOMAS ANDERSON

Monografia apresentada à

Faculdade de Comunicação da Universidade de Brasília como requisito parcial para obtenção do grau de bacharel em Comunicação Social com habilitação em Comunicação Organizacional.

Orientador: Prof. Dr. Mauro Giuntini Viana 



\section{EMBRIAGADO DE AMOR E SANGUE NEGRO: MANIFESTAÇÕES DE SILÊNCIO VERBAL E INCOMUNICAÇÃO NOS FILMES DE PAUL THOMAS ANDERSON}

Monografia apresentada à Faculdade de Comunicação da Universidade de Brasília como requisito parcial para obtenção do grau de bacharel em Comunicação Social com habilitação em Comunicação Organizacional.

Orientador: Prof. Dr. Mauro Giuntini Viana

BANCA EXAMINADORA

Prof. Dr. Mauro Giuntini Viana

(Orientador)

Prof. João Batista Lanari Bo

(Examinador)

Prof. Dr. Pablo Gonçalo Pires de Campos Martins

(Examinador)

Prof. Dr. Sérgio Araújo de Sá

(Suplente) 



\section{AGRADECIMENTOS}

Nos últimos quatro anos, a Universidade de Brasília - UnB me proporcionou uma experiência incomparável. Da felicidade ao descobrir o ingresso na Faculdade de Comunicação aos amigos que fiz durante esta trajetória, são inúmeras as lembranças que irão me acompanhar na etapa iniciada após a defesa desta monografia. Infelizmente, não tenho como, aqui, agradecer a todos, pois as páginas não seriam suficientes. No entanto, preciso reconhecer o papel de algumas pessoas que foram fundamentais para a concretização deste momento.

Ao Prof. Dr. Mauro Giuntini, que sempre se colocou à disposição para me auxiliar durante todo o meu percurso na Unb, e aceitou prontamente o convite para orientar este projeto. Seu conhecimento, incentivo e paciência foram primordiais para que eu conseguisse desenvolver e organizar todas as ideias que deram origem ao trabalho. Muito obrigada pela dedicação.

À Profa ${ }^{\text {Da }}{ }^{a}$ Gabriela Pereira de Freitas, a querida Gabee, meu maior exemplo dentro da Universidade de Brasília. O carinho e a admiração que sinto por ela transcendem a gratidão pelos ensinamentos acadêmicos. Mais que uma profissional brilhante, ela também é um ser humano incrível que, tenho certeza, continuará me inspirando para além dos portões da universidade.

Aos professores com os quais tive o prazer de estudar ao longo dos oito semestres dentro da UnB, tanto na Faculdade de Comunicação como em outros departamentos. Cada um deles contribuiu ativamente para a minha formação.

Ao meu irmão, Marcos Portela, minha maior preciosidade.

Ao meu melhor amigo canino, Quixote, pelas madrugadas ao meu lado enquanto eu escrevia esta monografia.

E, finalmente, ao Joaquim Pedro, meu companheiro para toda a vida. Obrigada por tudo. Amo-te infinitamente. 



\section{RESUMO}

Revelado para a indústria cinematográfica no início da década de 1990, após ter um curta-metragem selecionado pelo laboratório do Sundance Film Festival, o diretor norte-americano Paul Thomas Anderson é considerado um dos principais nomes da renovação do cinema dos Estados Unidos nas últimas duas décadas. Abordando temas que vão desde o esvaziamento cultural sofrido pela sociedade ocidental até o papel da figura masculina na contemporaneidade, Anderson dirigiu e roteirizou oito filmes de longametragem ao longo de seus 22 anos de carreira. Contudo, além dos eixos temáticos apresentados, existem outros elementos que dão unidade a sua obra, tal como o desenvolvimento de personagens socialmente desajustadas, isoladas, que demonstram inabilidade em se comunicar e, muitas vezes, encontram no silêncio um refúgio para seus conflitos. Outra característica marcante das tramas enredadas por Anderson é o uso da música como componente crucial para a compreensão do estado de espírito de suas personagens e do discurso construído pelo diretor. Diante desse contexto, o presente trabalho tem o objetivo de analisar as produções Embriagado de amor e Sangue negro, dirigidas por Anderson, com o intuito de compreender de qual maneira o cineasta utiliza a incomunicação e o silêncio como elementos narrativos. Para tanto, foi realizada uma breve contextualização acerca da história do som e do silêncio no cinema, bem como a fundamentação de tópicos como a função dos diálogos e da música nos filmes.

Palavras-chave: Paul Thomas Anderson; Embriagado de amor; Sangue negro; incomunicação; silêncio; cinema. 



\begin{abstract}
Revealed for the film industry in the early 1990s, after one of his short films was selected by the Sundance Film Festival's lab, American director Paul Thomas Anderson is considered one of the top names in American filmmaking in the last two decades. Addressing subjects ranging from the cultural emptying of Western society to the role of the male figure in contemporary times, Anderson directed and wrote eight feature-length films throughout his 22-year career. In addition to the thematic axes presented, there are other elements that give unity to his work, such as the development of misfit and isolated characters, who show inability to communicate and often find in silence a refuge for their conflicts. Another striking feature of the plots entangled by Anderson is the use of music as a crucial component in understanding the mood of his characters and the director's own discourse. In this context, the present work aims to analyse the films Punch-drunk love and There will be blood, directed by Anderson, in order to understand how the filmmaker uses incommunication and silence as narrative elements. For that, a brief contextualization was made on sound and silence in film history, as well as the function of dialogues and music.
\end{abstract}

Keywords: Paul Thomas Anderson; Punch-drunk love; There will be blood; incommunication; silence; film. 



\section{LISTA DE FIGURAS}

Figura 1 - Assinatura de Plainview mostrada pela primeira vez 54

Figura 2 - Assinatura de Plainview mostrada já ao final do filme 54

Figura 3 - Assinatura de Lady Lyndon no cheque anual para Barry 55

Figura 4 - lluminação natural em Sangue negro 56

Figura 5 - lluminação natural em Barry Lyndon 56

Figura 6 - Cena vermelha de Caminhos perigosos 57

Figura 7 - Exemplo de alusão à cena vermelha de Caminhos perigosos em Boogie nights 58

Figura 8 - Cena final de Boogie nights 58

Figura 9 - Cena final de Touro indomável 58

Figura 10 - Lena e Barry no restaurante 63

Figura 11 - Barry no supermercado e mulher de vermelho ao fundo 64

Figura 12 - Corredor no prédio de Lena 65

Figura 13 - Corredor de embarque no aeroporto 65

Figura 14 - Barry imerso nas sombras $\quad 65$

Figura 15 - Barry leva o harmônio até o apartamento de Lena 66

Figura 16 - Barry na loja de Dean com o telefone quebrado 69

Figura 17 - Corpo de Henry na cova com petróleo 77

Figura 18 - Última cena de Sangue negro 78

Figura 19 - Desaprovação de Daniel ao comentário dos empresários $\quad 80$

Figura 20 - Daniel confuso com a indiferença de Henry 81

Figura 21 - Incredulidade de Daniel perante a possibilidade de Henry $\begin{array}{ll}\text { ser um impostor } & 81\end{array}$

Figura 22 - Daniel chega à conclusão que está sendo enganado 81

Figura 23 - Daniel se entrega à raiva 81 



\section{SUMÁRIO}

INTRODUÇÃO

CAPÍTULO I - SOM, SILÊNCIO, FALA E INCOMUNICAÇÃO

1.1 BREVE HISTÓRIA DO SOM E DO SILÊNCIO NO CINEMA

1.2 A FUNÇÃO DOS DIÁLOGOS

1.3 O SILÊNCIO COMO MATERIAL EXPRESSIVO

1.4 A MÚSICA DOS FILMES

1.5 OS CAMINHOS DA INCOMUNICAÇÃO NO CINEMA 37

1.6 MÉTODO DE PESQUISA

CAPÍTULO II - O UNIVERSO CINEMATOGRÁFICO DE PAUL THOMAS ANDERSON

2.1 OBRAS, CARACTERÍSTICAS E TEMÁTICAS ABORDADAS

2.2 CONSTRUÇÃO DE PERSONAGENS

2.3 INFLUÊNCIAS: ALTMAN, SCORSESE E KUBRICK

CAPÍTULO III - EMBRIAGADO DE AMOR

3.1 PUNCH-DRUNK BARRY

3.2 MANIFESTAÇÕES DE INCOMUNICAÇÃO 66

3.3 MÚSICA PARA OS EMBRIAGADOS

CAPÍTULO IV - SANGUE NEGRO

4.1 SANGUE E PETRÓLEO

4.2 O SILÊNCIO DE PLAINVIEW 



\section{INTRODUÇÃO}

$\mathrm{O}$ advento do som provocou transformações profundas na maneira como o cinema conta suas histórias. Apesar da importância dos diálogos na transmissão de informações sobre a narrativa, existem momentos da trama que são representados com maior eloquência pelo silêncio ou pela incapacidade de alguma personagem em conseguir se comunicar. Nestas ocasiões, o silenciamento verbal e a incomunicação são utilizados como elementos expressivos, capazes de despertar nos espectadores as mais diversas reações. Os diretores podem utilizar estratégias narrativas variadas para construir significados e transmitir emoções sem se apoiarem no peso das palavras, seja por meio das expressões faciais e corporais dos atores, posicionamentos e movimentos de câmera, escolhas de estilo de montagem ou composição de trilhas musicais.

Da mesma forma como o som amplia as possibilidades narrativas de um filme (MANZANO, 2014), o silêncio traz consigo capacidade semelhante, sobretudo quando atua como formador de sentido. A respeito dessa função significadora, particularmente no que se refere à fala, Eni Orlandi enuncia que "quando não falamos, não estamos apenas mudos, estamos em silêncio: há o 'pensamento', a introspecção, a contemplação etc" (2011, p. 35). Ou seja, o ato de calar pode remeter, também, à dimensão interna e espiritual. No caso do cinema, a ausência ou interrupção de diálogos interfere na construção das personagens, bem como no seu papel para o desenvolvimento da trama.

Em sua obra introdutória sobre as principais teorias do cinema, Robert Stam (2013) relembra que, para o compositor e teórico do audiovisual Michel Chion, tanto a realização cinematográfica quanto a crítica e os estudos acerca dessa linguagem privilegiam o papel desenvolvido pela vocalização nos filmes. A própria introdução do som no meio se deu para possibilitar a veiculação da voz, fazendo com que, historicamente, as demais camadas sonoras além do diálogo fossem relegadas a segundo plano e submetidas à predominância dos impactos causados pela comunicação verbal e pelas imagens.

Para amparar o argumento de Stam sobre a função primária do som no cinema, vale acrescentar que o recurso da fala, em determinados momentos, diminui 
a ambivalência dos sentidos que podem ser provocados pelas construções visuais (GAUDREAULT; JOST, 2009). Isto é, quando há a oralização expositiva por parte da personagem, esteja ela engajada em um diálogo ou monólogo, a narrativa imagética fica, muitas vezes, condicionada ao que é dito, estreitando as possibilidades interpretativas.

Tal fator não significa que o som não desenvolva um papel importante na construção desse silêncio ou de uma possível inabilidade de comunicação. Até porque, não são raras as vezes em que a existência de outros componentes sonoros, como as músicas, atuam como reforço do momento de pausa verbal. A enunciação clara e audível das palavras em diálogos é um dos elementos mais eficazes para transmitir informações sobre a história. Dessa forma, a rarefação ou mesmo suspensão desse recurso, tão valorizado no audiovisual, assim como seus efeitos na trama, constituem relevante objeto de estudo narratológico.

Com o objetivo de examinar os silenciamentos verbais gerados por interrupções ou a supressão de diálogos advindos da inabilidade de comunicação no cinema ficcional contemporâneo, foram selecionadas para análise duas obras do diretor estadunidense Paul Thomas Anderson: Embriagado de amor (Punch-drunk love, 2002) e Sangue negro (There will be blood, 2007).

A escolha das obras de Anderson como universo da pesquisa provém de uma forte motivação pessoal, representada pela ligação afetiva e emocional existente com os filmes do diretor. Além disso, outro fato que justifica a escolha é seu diferencial dentro da produção acadêmica brasileira. Desde o lançamento de Boogie nights - prazer sem limites (Boogie nights, 1997), segundo longa-metragem de Anderson, seus filmes são considerados um reflexo dos conflitos existenciais vividos pela sociedade contemporânea, fomentados por uma cultura focada no consumo e corroída pela midiatização (SPERB, 2013).

Além das temáticas que sugerem uma autorreflexão do realizador quanto à sociedade na qual está inserido, Anderson - que mantém o controle criativo de suas produções - também demonstra consistência e virtuosismo técnicos, considerado pela crítica cinematográfica um auteur ${ }^{1}$ (autor) da contemporaneidade (SPERB, 2013). Todavia, mesmo apresentando uma filmografia expressiva, tanto em termos

\footnotetext{
${ }^{1}$ Termo cunhado pelos colaboradores da Cahiers du Cinéma, revista francesa que serviu como base teórica para o movimento cinematográfico Nouvelle Vague. De forma geral, a designação auteur é usada para destacar diretores que imprimem em seus filmes uma clara visão pessoal e ideológica, que vai dos temas abordados à forma empregada (MASCARELLO, 2012).
} 
de forma quanto de conteúdo, a produção acadêmica sobre sua obra ainda é escassa, especialmente no Brasil, o que ressalta a singularidade da proposta deste trabalho. A definição do tema também se deu levando em consideração sua originalidade, pois a maioria das pesquisas sobre sua obra está focada em questões como a representação da fragilidade masculina na contemporaneidade e as relações familiares. Olhar para os filmes de Anderson com a perspectiva do silêncio e da incomunicação é introduzir novas possibilidades de interpretação à filmografia do diretor.

Nesse contexto, o principal objetivo do estudo é analisar as possibilidades narrativas das manifestações de silêncio verbal e incomunicação nos filmes Embriagado de amor e Sangue negro. Para entender a presença desses elementos nas obras do cineasta, o trabalho também busca: examinar o papel dos diálogos na narrativa cinematográfica; explorar a construção das personagens e o desenvolvimento das tramas dos filmes em análise; e compreender como a música pode contribuir para acentuar as dificuldades de comunicação das personagens nos dois filmes em questão.

De modo a alcançar os resultados almejados, a pesquisa busca verificar com olhar crítico os contextos relativos ao seu objeto. Para tal, é preciso estabelecer uma linha teórica de abordagem que forneça os subsídios necessários para a efetividade da análise. Assim, a metodologia utilizada tem sua base na linha neoformalista dos autores David Bordwell e Kristin Thompson.

Em linhas gerais, os neoformalistas defendem uma abordagem cognitiva dos filmes, cuja premissa consiste em uma interpretação total do texto cinematográfico por meio de seus aspectos formais. Juntamente com esse modelo, é explorado também o entendimento de desconstrução e reconstrução do filme, formatado por etapas que englobam a descrição e a interpretação da obra.

Após esta parte introdutória, que contextualiza o tema pesquisado, a monografia se apresenta dividida da seguinte forma: o primeiro capítulo aborda questões acerca do som na história do cinema, com ênfase nas mudanças acarretadas pela transição do cinema mudo para o falado. As evoluções tecnológicas que possibilitaram o refinamento no tratamento do som e a chegada do formato digital também estão presentes, bem como o papel da trilha musical nos filmes. O capítulo ainda trata da função dos diálogos, do uso do silêncio como 
material expressivo e da incomunicação. Ao final, é feita a apresentação da metodologia de análise adotada.

No capítulo II são expostas as características do cinema de Paul Thomas Anderson como diretor, desde os principais eixos temáticos abordados até as técnicas mais utilizadas. O segundo capítulo também possui um tópico dedicado à construção das personagens em seus filmes, além da identificação de três diretores que influenciam o estilo cinematográfico de Anderson: Robert Altman, Stanley Kubrick e Martin Scorsese.

Os capítulos III e IV apresentam as análises de Embriagado de amor e Sangue negro, respectivamente. Para tal, foi escolhida a seguinte estrutura: apresentação do filme, com a identificação de temáticas gerais e técnicas aplicadas; investigação das manifestações de incomunicação (Embriagado de amor) e silêncio verbal (Sangue negro); e análise da relação entre trilha musical e estado emocional das personagens. 


\section{CAPÍTULO I}

\section{SOM, SILÊNCIO, FALA E INCOMUNICAÇÃO}

O presente capítulo tem como finalidade apresentar os fundamentos teóricometodológicos que dão suporte à pesquisa desenvolvida nesta monografia, sendo eles o som, o silêncio, a fala (representada pelos diálogos cinematográficos), a trilha musical e a incomunicação. Inicialmente, é realizada uma abordagem histórica do som e do silêncio no cinema, desde o momento de transição do cinema mudo para o cinema falado até os dias atuais. Nessa parte, o texto se apoia principalmente em ideias contidas nas obras de autores como Jacques Aumont (2012), André Gaudreault e François Jost (2009), David Bordwell e Kristin Thompson (2001) e Michel Chion (1994).

Ao discorrer sobre as funções dos diálogos no filmes, são levadas em consideração as formulações de Robert McKee (2016) acerca do tema. Felipe Forain (2013) e Eni Orlandi (2007) compõem o corpo teórico no que se refere às questões do silêncio como material expressivo, enquanto as proposições de Norval Baitello Junior (2005) fundamentam as colocações relativas à incomunicação. E, para estabelecer o papel da trilha musical nas obras audiovisuais, o trabalho recorre aos preceitos contidos em Chion (2011), Annabel J. Cohen (1998) e André Baptista (2007).

Por fim, o capítulo se encarrega de descrever a metodologia adotada para a análise dos objetos da pesquisa, baseada na linha noeformalista de Bordwell e Thompson (2001). A escolha da metodologia se deu com o intuito de explorar o máximo dos procedimentos e sistemas que constituem a técnica de análise fílmica.

\subsection{BREVE HISTÓRIA DO SOM E DO SILÊNCIO NO CINEMA}

A partir da metade do século $X X$, diretores de cinema como Ingmar Bergman, Alfred Hitchcock e Andrei Tarkovsky começaram a perceber o silêncio como uma parte integrante do espaço sonoro (ENCABO, 2015). O recurso passa, então, a ser explorado como um forte meio de expressão, uma ferramenta crucial para o desenvolvimento dramático da narrativa cinematográfica (idem). Porém, a percepção 
alcançada por esses diretores só foi possível pelo fato de o próprio cinema permitir que assim acontecesse, já que a admissão do silêncio se torna viável apenas quando há um ambiente onde circulam som e linguagem (SONTAG, 2015).

A consolidação do cinema no começo do século $X X$ deu origem a um período marcado pelo domínio das imagens (COSTA, 2012). A explicação para esse fenômeno está relacionada com a ausência de diálogos e outros sons diegéticos, já que o cinema é mudo em sua gênese. Esse início silencioso proporcionou o desencadeamento de uma maior acuidade na construção harmônica entre a intensidade das expressões faciais e corporais dos atores e a composição visual (AUMONT, 2012). No entanto, a inexistência dos sons endógenos não significava, necessariamente, que a experiência cinematográfica era silenciosa. Este fator deveu-se, em grande parte, à presença de recursos sonoros externos, como comentários à história por meio de um narrador presente na sala de exibição ou o acompanhamento musical simultâneo, realizado geralmente ao vivo por pianistas ou pequenas orquestras (GAUDREAULT; JOST, 2009).

Quando o cinema passa a ser falado, em 1927, expande-se também a gama de possibilidades criativas da linguagem, pois o novo recurso atribui outras perspectivas à forma como as imagens são percebidas e interpretadas (BORDWELL; THOMPSON, 2001). Isto se deve, talvez, aos múltiplos aspectos de apresentação do som em um filme: Bordwell e Thompson (2001), por exemplo, categorizam estas manifestações como ruído, discurso e música - sendo os dois últimos mais relevantes para a presente pesquisa -, e explicam como cada uma delas pode possuir diferentes funções dentro da narrativa cinematográfica.

De maneira geral, os autores propõem quatro papéis essenciais que os elementos sonoros desempenham, e todos eles estão fundamentados no princípio de que para estudar e entender o som é necessário passar a ouvir os filmes, não só assisti-los. Eles explicam que como a visão é, por via de regra, o sentido que as pessoas usam com maior ênfase para colher informações, os sons são muitas vezes ignorados ou percebidos como um mero complemento das impressões visuais. Esta prática, quando transportada para o cinema, reforça a noção de que os fatores sonoros, exceto o discurso verbal, são apenas um acompanhamento para a concepção inaugural da linguagem cinematográfica: as imagens em movimento (BORDWELL; THOMPSON, 2001). 
Contudo, perceptivelmente ou não, as técnicas de som têm a habilidade de causar efeitos sensoriais que amplificam a experiência dos espectadores (BORDWELL; THOMPSON, 2001). Nessas circunstâncias, os autores elencam os seguintes padrões como funções elementares do som no cinema: a capacidade de promover uma espécie de "sincronia dos sentidos" ao conectar impressões auditivas e estímulos visuais; a eficácia em moldar a assimilação e leitura das imagens; a expansão do universo criativo; e as atribuições relativas ao silêncio.

Em relação à última função citada acima, o retorno da discussão ao momento de transição do cinema mudo para o falado é quase inevitável. E, aqui, é possível notar uma certa contradição. Enquanto Stam (2013) afirma, como mencionado na introdução deste trabalho, que o som surge para justamente dar voz aos atores, é sabido que, exatamente por este motivo, o recurso foi recebido com cautela pelos profissionais da área. Os debates acerca da nova tecnologia e suas possibilidades expressivas eram permeados sobretudo pelas limitações técnicas causadas após a inserção do som na linguagem cinematográfica - tais como restrições na movimentação das câmeras e baixa qualidade na captação do áudio - e pela verbalização excessiva das personagens.

De acordo com Bordwell e Thompson (2001), os estudiosos contrários à novidade não se opunham à música e aos efeitos sonoros, pois estes já eram acrescentados exteriormente e enriqueciam a experiência. A resistência era direcionada ao uso demasiado dos diálogos que, além de outras consequências, romperia com as limitações do cinema em reproduzir fielmente todos os aspectos da realidade - característica apreciada por alguns teóricos da época, como Rudolf Arnheim.

Mesmo com as evoluções tecnológicas que possibilitaram o aprimoramento da dimensão sonora nos filmes, o tópico continuou a levantar algumas discussões. Chion questiona em seu livro Audio-Vision (1994) se ainda hoje existe um certo olhar saudosista em relação ao cinema anterior à transição para o cinema falado, uma vez que o debate sobre o som sempre retorna a esse momento. É como se após essa ruptura não houvesse ocorrido qualquer outro tipo de grande avanço a ser analisado. Chion também afirma que não fazia sentido direcionar críticas apenas ao

\footnotetext{
${ }^{2}$ Este conceito utilizado por Bordwell e Thompson é derivado do termo synchronization of senses, cunhado pelo diretor russo Sergei Eisenstein.
} 
campo do som diante das possibilidades existentes à época, visto que não ocorreram muitos progressos técnicos no campo visual.

Vale ressaltar, contudo, que o livro de Chion foi escrito antes da revolução digital no cinema atingir o impacto transformador em todos os elos da cadeia produtiva da atualidade, condição que provocou mudanças na linguagem cinematográfica no que se refere, também, à imagem (como o ressurgimento do 3D com um alto nível de qualidade técnica).

Independentemente de uma visão conservadora que possa existir, desde meados de 1970 os estudos sobre o som tornaram-se cada vez mais frequentes, ganhando força no início da década de 1990 com a introdução do digital. As evoluções técnicas permitiram que fossem exploradas outras potencialidades da gravação, mixagem e reprodução sonoras, principalmente em produções de grande orçamento (BORDWELL; THOMPSOM, 2001).

Entretanto, à medida que ocorrem os avanços tecnológicos na área, observase a produção de filmes cada vez mais ruidosos, repletos de efeitos que invadem os ouvidos dos espectadores de forma avassaladora (MANZANO, 2014). Esta sensação de um som imersivo se deve, em muito, à própria configuração das salas de cinema, que são equipadas tecnicamente de acordo com as tecnologias vigentes para o espectador tirar maior proveito da experiência. O retorno a uma concepção de silêncio, diante deste contexto, surge como um repouso quase biológico, um apelo ao descanso auditivo, confrontando toda a profusão de barulhos presentes nos filmes atualmente.

A resistência do silêncio frente ao cenário caótico produzido pela abundância de camadas de sons acarreta indagações que não se restringem, apenas, à exclusão das fontes tonantes. Até porque, para Chion (1994), o silêncio sonoro seria uma construção forjada, já que sua totalidade dificilmente será atingida, caracterizando-se mais como uma espécie de impressão. Assim, essas reflexões se relacionam também com as diversas formas incorporadas pelo silêncio como recurso estético da linguagem cinematográfica capaz de gerar sentidos, sendo a omissão da fala uma delas.

Paradoxalmente, o ato intencional de não falar pode provocar uma série de subterfúgios comunicacionais (ORLANDI, 2011). Nele podem ser criados os significados e arquitetados os sistemas de exteriorização sonora, inclusive vocal. E, 
diante do reconhecimento da presença do silêncio verbal nos filmes como um fenômeno capaz de comunicar e produzir sentidos, a análise dessas ocorrências poderia auxiliar em uma maior compreensão das obras de cineastas contemporâneos que encontram no elemento um recurso narrativo, caso de Paul Thomas Anderson.

\subsection{A FUNÇÃO DOS DIÁLOGOS}

Para discorrer sobre o silenciamento verbal nos filmes, é preciso, antes de tudo, entender a importância e as funções da fala para o cinema. Como ressaltado anteriormente, o som surge para dar voz aos atores em uma tentativa de aproximar ainda mais a experiência cinematográfica da realidade. Com isso, os diálogos se tornam um dos elementos responsáveis por conduzir a narrativa. É por meio deles que o espectador recebe as principais informações sobre o contexto no qual a trama se desenrola, sobre as personagens e os demais componentes necessários para a compreensão da história.

Nos primórdios do cinema, mesmo com a ausência da sonorização diegética, letreiros na tela indicavam supostos diálogos que as personagens travavam entre si. Ou seja, ainda que em forma de texto, a existência dessas explicações se fazia pertinente para auxiliar o entendimento. Para aqueles que não possuem qualquer impedimento físico, a fala, enquanto parte integrante da linguagem, apresenta-se como um dos recursos mais eficazes no processo de comunicação. De tal maneira, é evidente o peso que os diálogos possuem para a narrativa cinematográfica.

Contudo, comunicar não se trata apenas de verbalização, porque existem outros meios de expressão que podem ser utilizados para transmitir informações e significados, como a linguagem corporal, o olhar e o próprio silêncio. Os diálogos criados para o cinema, nesse caso, atendem a uma série de requisitos, que levam em consideração até o vocabulário adequado para cada tipo de filme. Sendo assim, pensar em funções da fala, e dos diálogos especificamente, está atrelado, também, a questões técnicas.

Existem diretores de cinema conhecidos pela liberdade que dão aos atores para improvisar em cena, como Robert Altman, por exemplo (SPERB, 2013). Mesmo assim, o improviso segue uma linha de pensamento previamente exposta no roteiro. 
$E$, por mais que o ator se afaste do que estava escrito e crie diálogos que não existiam, essa criação ainda está apoiada dentro de um contexto narrativo estabelecido com antecedência. É sabido que algumas das falas mais famosas do cinema foram improvisadas, como na antológica cena de Robert De Niro em Taxi Driver (Taxi Driver, 1976) conversando com seu reflexo no espelho. Contudo, essa sequência está de acordo com a construção da personagem e a história ali sendo contada.

O que a personagem diz ou deixa de dizer repercute profundamente na sua recepção pelo espectador, e isso tem ligação com o caráter de expressividade atribuído à fala nas relações sociais. Por essa razão, a construção dos diálogos e a maneira como eles são inseridos representam uma parcela muito significativa na forma como o público se identifica com as personagens que dão vida à trama.

Robert McKee (2016) explica que, ao escrever diálogos, o roteirista precisa incorporar nessas falas as nuances e complexidades da narrativa. Aquilo que é dito pelas personagens, especialmente nos momentos de conflito, deve indicar até os pensamentos e sentimentos que não são exteriorizados. Logo, o processo de construção dos diálogos leva em consideração, também, os sentidos por trás das palavras proferidas ou até o que não será dito.

Em Dialogue: the art of verbal action for the page, stage, and screen (2016), McKee classifica os diálogos como sendo dramatizados e narrativos: o primeiro refere-se às falas ditas em cena, inclusive quando se tratam de monólogos; e o segundo diz respeito à narração, à vocalização extradiegética. $O$ autor ainda acrescenta que, independentemente da natureza, os diálogos possuem três funções elementares: de exposição, caracterização e ação.

A exposição proposta por McKee abrange as informações do universo ficcional no qual a audiência irá imergir. $O$ termo, em si, não se restringe aos diálogos, pois abarca todos os componentes visuais e sonoros que são postos à disposição do espectador no intuito de fazê-lo envolver-se com a trama. Contudo, McKee elucida que a função expositiva do diálogo reside na capacidade de traduzir em palavras praticamente tudo aquilo que está contido no subtexto de uma imagem.

O autor afirma que, "virtualmente, qualquer coisa expressa em imagens ou explicada na narração pode ser aplicada ao diálogo. Portanto, a primeira função do diálogo é passar a exposição para o leitor ou audiência" (MCKEE, 2016, p. 22-23, 
tradução nossa) ${ }^{3}$. No entanto, essa exposição precisa ser controlada para que não haja perda de interesse na história. McKee salienta que os detalhes passados ao espectador por meio de diálogos obedecem um determinado ritmo, e as informações devem ser dadas em momentos precisos e apenas quando necessárias, evitando assim a exposição forçada.

A segunda função exposta por McKee trata da composição das personagens e como elas são representadas em seus diálogos. $O$ autor divide essa função em "personagem verdadeira" e "caracterização". A personagem verdadeira remete à dimensão moral e psicológica. Já a caracterização encontra-se naquilo que é percebido de forma superficial, como o comportamento. Essas características combinadas visam deixar o espectador intrigado, convencendo-o da humanidade e individualidade da personagem.

Quando os diálogos entram em cena, expressos por personagens que possuem uma junção ideal de verdade e caracterização, a impressão transmitida para o espectador é que se trata de alguém único. Geralmente, personagens inesquecíveis dos filmes, cujas falas são largamente reproduzidas e referenciadas, foram concebidas por roteiristas que encontraram um equilíbrio entre os dois recursos.

A última função apresentada por McKee é aquela encarregada de preparar a personagem para a ação, seja ela mental, física ou verbal. Os diálogos encaixam-se na categoria verbal e, segundo o autor, precisam ser analisados em conjunto com as ações tomadas pelas personagens após o ato de falar. Assim, o espectador saberá se as motivações expressas verbalmente condizem com as atitudes, desvendando as camadas que conformam a personagem.

McKee ainda discorre sobre questões como os clichês nas falas, os diálogos vazios de sentido, as metáforas e a escolha de vocabulário. Todavia, esses campos são desdobramentos possíveis dentro das funções já explicadas. No entanto, as reflexões do autor sobre o silenciamento merecem ser destacadas. Ele considera o silêncio verbal como uma "economia da linguagem", mas não necessariamente uma economia de informação ou significados. McKee sugere o exercício de retornar às origens do cinema e desenhar uma cena estritamente visual. Mesmo com

\footnotetext{
${ }^{3}$ No original: "Virtually anything expressed in images or explained in narration can be implied in dialogue. Therefore, the first function of dialogue is to pass exposition to the eavesdropping reader/audience." (MCKEE, 2016, p. 22-23).
} 
personagens interagindo entre si, se for possível para a audiência capturar os sentidos atribuídos à sequência apenas por meio da composição de imagens, os diálogos não são exigidos.

É bem verdade que muitos filmes se valem do diálogo para encobrir falhas nos roteiros ou até outras carências técnicas. Geralmente, obras assim estão repletas de superexposições que não acrescentam muito à história. Contudo, o excesso de diálogos nem sempre significa que o enredo do filme é pobre e as falas, vazias. Há diretores e roteiristas que prezam por narrativas carregadas de diálogos e conseguem torná-los seus pontos fortes, como Woody Allen e Quentin Tarantino.

Tarantino é responsável pelos roteiros de seus filmes, e duas das principais características de suas narrativas são a violência gráfica e os diálogos prolongados. As personagens nas obras dele são todas eloquentes, o que resulta em poucos momentos de pausa verbal. Os diálogos são interrompidos apenas para dar lugar às cenas em que a selvageria é instaurada. Ironicamente, o único atributo capaz de equiparar-se à prolixidade das personagens de Tarantino é a sede de sangue que possuem.

Os filmes do diretor são reconhecidos, também, por essa loquacidade, e não de forma pejorativa. Muitos dos diálogos confeccionados por ele tornaram-se referência para a cultura pop, como a conversa entre as personagens de Samuel L. Jackson e John Travolta sobre um hambúrguer em Pulp fiction - tempos de violência (Pulp fiction, 1994), ou a discussão de várias personagens no início de Cães de aluguel (Reservoir dogs, 1992) sobre dar ou não gorjetas para garçons.

Outro diretor que escreve seus próprios roteiros e faz filmes com diálogos excessivos é Woody Allen. E, assim como acontece com Tarantino, esse atributo é apreciado em suas histórias. As falas nas produções de Allen são sagazes, exigindo que o espectador esteja atento às dicas fornecidas por ele por meio dos diálogos para apreender o subtexto narrativo. Até porque, as personagens de Allen raramente dizem aquilo que realmente pretendem. Um exemplo disso é a cena de Noivo neurótico, noiva nervosa (Annie Hall, 1977), onde Alvy (Woody Allen) e Annie (Diane Keaton) conversam sobre banalidades e uma legenda é inserida para expor ao público o que as personagens gostariam de dizer, ao invés daquilo que dizem de fato. 
Seja falando mais ou menos, o papel do diálogo é guiar o espectador durante a história. Como a audiência de hoje não está habituada ao silenciamento verbal nos filmes, diretores que optam por essas pausas exploram outros recursos expressivos, como a trilha sonora. Porém, a eficácia dos diálogos, escassos ou não, encontra-se no seu equilíbrio com os demais elementos da linguagem cinematográfica. Vale pontuar, também, que os diálogos requerem conhecimento não só das técnicas de escrita, mas da natureza humana. Afinal, a dinâmica estabelecida pela fala, além de determinar a comunicação entre personagens, constrói a ponte que une o mundo fictício à realidade do público.

\subsection{SILÊNCIO COMO MATERIAL EXPRESSIVO}

O silêncio e a fala dividem a mesma área de significação: o sistema da comunicação. Enquanto o ato de falar se apresenta como a execução plena desse processo, o silêncio surge para confrontá-lo (FORAIN, 2013). A partir desse entendimento, não seria incorreto inferir que, para que o silêncio participe da comunicação, é preciso que exista uma fala interrompida (idem). Ainda sobre essa percepção, Felipe Forain acredita que o silêncio é uma abertura para formas diferentes de estabelecer a comunicação pretendida. Assim, falar e silenciar são complementares e não excludentes.

Em As formas do silêncio (2007), Eni Orlandi também articula a respeito da fala e do silenciamento, chamada por ela de "política do silêncio". Para a autora, assim como a fala, o silêncio é repleto de multiplicidades, e não deve ser encarado como ausência, pois suscita tantas possibilidades interpretativas quanto a própria verbalização. Orlandi diz: "O silêncio, mediando as relações entre linguagem, mundo e pensamento, resiste à pressão de controle exercida pela urgência da linguagem e significa de outras e muitas maneiras" (2007, p.37).

Orlandi ainda acredita que os sentidos produzidos pelo silenciamento provêm da posição adotada por aquele que silencia. Ele não surge espontaneamente, portanto. Está atrelado a pontos de vistas específicos, pois a escolha em não dizer algo é orientada pelos sentidos que o interlocutor espera ocultar. Logo, o que ele diz e o que omite significam de maneira igual, fazendo com que fala e silêncio precisem 
ser levados em consideração conjuntamente no exercício de interpretar as intenções do sujeito.

As asserções de Forain e Orlandi também são compartilhadas por Susan Sontag no ensaio A estética do silêncio, em seu livro A vontade radical (2015). A autora afirma que "um indivíduo que permanece em silêncio torna-se opaco ao outro; o silêncio de alguém inaugura uma série de possibilidades de interpretação desse silêncio, de imputação de discurso a ele" (2015, p.24). Ao relacionar a afirmação de Sontag com os entendimentos propostos por Forain e Orlandi, é possível concluir, então, que o silêncio comunica e significa, e essa significação também pode ser alheia àquela atribuída pela pessoa que cala.

Ao deslocar esses raciocínios para o cinema, torna-se considerável a ideia de um silêncio como recurso expressivo, mais precisamente do silenciamento verbal. Porém, antes de tudo, é importante aceitar o silêncio como um elemento narrativo também. Nesse caso, e levando em consideração a finalidade deste trabalho, faz-se necessário explorar as possibilidades existentes nas aberturas dos filmes Sangue negro, de Anderson, e 2001: Uma odisseia no espaço 2001: A space odyssey, 1968), dirigido por Stanley Kubrick.

Nos 14 minutos iniciais de Sangue negro não há diálogos, apenas grunhidos emitidos pelo protagonista, Daniel Plainview (Daniel Day-Lewis), quando se acidenta seriamente trabalhando dentro de uma mina e, posteriormente à cena, o início de sua carreira no ramo de prospecção de petróleo. Em 2001: Uma odisseia no espaço, os primeiros 10 minutos também são marcados pela ausência de diálogos, ouvindose apenas os guinchados dos macacos. E, assim como os macacos de Kubrick dão origem à humanidade, o silêncio e o acidente de Plainview dão origem à face da personagem explorada por Anderson.

A experiência causada por estas duas sequências é primordialmente visual, já que não existe o estímulo sonoro da verbalização. Mesmo com a presença da trilha musical e outros ruídos, não há a interferência dos diálogos nas cenas, o que instiga o espectador a formar suas próprias próprias interpretações das imagens ali postas e, consequentemente, dos silêncios. Com isso, tanto Kubrick quanto Anderson usam o silêncio como um artifício para preencher as lacunas deixadas pela ausência da fala. Por mais contraditório que possa parecer, é justamente essa ambiguidade que 
faz do silenciamento nas duas obras um recurso para compreensão da história que os diretores pretendem contar.

Todavia, a abordagem de Anderson em Sangue negro e de Kubrick em 2001 em torno do silêncio não é exclusividade dos cineastas. Outros diretores também alcançaram destaque ao explorar as potencialidades do silenciamento verbal como instrumento expressivo. Um dos principais autores a lançar mão desse recurso foi o diretor sueco Ingmar Bergman. Entre 1961 e 1963, Bergman dirigiu Através de um espelho (Såsom i en spegel, 1961), Luz de inverno (Nattvardsgästerna, 1963) e O silêncio (Tystnaden, 1963), conhecidos posteriormente como Trilogia do Silêncio.

Os filmes são marcados pela escassez de diálogos, reflexo da crise existencial das personagens ao lidarem com as aflições humanas de uma vida aparentemente sem sentido. A subtração dos diálogos é compensada pela proximidade da câmera no rosto dos atores, capturando os mínimos movimentos e expressões. Assim, palavra alguma precisa ser proferida para descrever a apreensão de Martin (Max Von Sydow), em Através de um espelho, as dúvidas de Tomas (Gunnar Björnstrand), em Luz de inverno, ou o medo da morte de Ester (Ingrid Thulin), em O silêncio.

Em 2016, Martin Scorsese lançou Silêncio (Silence, 2016), um drama histórico sobre a presença de padres jesuítas portugueses no Japão do século XVII e a perseguição sofrida pelos cristãos no país à época. O silêncio sugerido por Scorsese remete à dimensão espiritual, que nasce dos conflitos religiosos travados internamente pelos homens de fé. Assim como em $A$ última tentação de Cristo (The last temptation of Christ, 1988), também de Scorsese, Silêncio faz alusão à falta de respostas de Deus diante da tortura e do sofrimento de seus filhos.

Da mesma forma como Ingmar Bergman indagou ao longo de praticamente toda sua filmografia (PUA, 2016) ${ }^{4}$, Scorsese pergunta em Silêncio e $A$ última tentação de Cristo: será o silêncio de Deus prova de sua não-existência? Os diretores não respondem a questão, mas desfrutam das possibilidades narrativas oferecidas pela linguagem cinematográfica para tensioná-la ao máximo. Em Silêncio, as paisagens contemplativas fotografadas por Rodrigo Prieto, em cenas cujo único som audível é aquele proveniente da natureza (obra da Criação), contrastam com o

\footnotetext{
${ }^{4}$ PUA, Phoebe. The silent God of Ingmar Bergman and Andrei Tarkovsky. 2016. Disponível em: $<$ http://www.fourbythreemagazine.com/issue/silent-god-of-bergman-and-tarkovsky>. Acesso em: 15 mai. 2018.
} 
silêncio das personagens, à espera de um pronunciamento divino que justifique seu calvário.

Nos 55 anos que distanciam a Trilogia do Silêncio de Bergman do cinema atual, as transformações que ocorreram no campo tecnológico em muito alteraram a percepção do silêncio nos filmes. As produções tornaram-se cada vez mais ruidosas e repletas de diálogos expositivos, como os blockbusters de super-heróis em voga no momento. Entretanto, muitos diretores têm se voltado para a quietude do silêncio verbal, privilegiando outros aspectos narrativos além dos diálogos.

Um exemplo recente dessa tendência é Dunkirk (Dunkirk, 2017), do britânico Christopher Nolan. Ganhador do Oscar 2018 nas categorias Edição e Mixagem de Som, Dunkirk, com 106 minutos de duração, quase não possui falas. A obra de Nolan, sobre a Batalha de Dunquerque ocorrida na França durante a Segunda Guerra Mundial, apoia-se na fotografia, na música e no silêncio verbal para criar os tensionamentos narrativos. A não-verbalização das personagens, por si só, denota um estado permanente de angústia e incerteza, que não requer a intervenção dos diálogos para intensificá-lo.

Em Um lugar silencioso (A quiet place, 2018), de John Krasinski, uma família é obrigada a se comunicar quase inteiramente por meio de $\mathrm{ASL}^{5}$ para poder sobreviver. A distopia de Krasinski traz uma Terra ocupada por alienígenas cegos, que encontram suas presas por meio dos sons, já que são dotadas de uma audição extremamente sensível. Tal condição exige o completo silêncio das personagens. As atividades mais corriqueiras como cozinhar e comer demandam extremo cuidado e a ausência absoluta de barulhos. Como em qualquer filme de terror, os gritos de medo existem, mas deles não são emitidos qualquer som.

Diferentemente de $O$ artista (The artist, 2011), cuja intenção é justamente mimetizar um filme mudo e homenagear o momento de transição para o cinema falado, Um lugar silencioso abre mão dos diálogos para explorar outros aspectos sonoros de um filme, como ruídos e trilha musical. Para acentuar ainda mais a experiência, uma das personagens (e a atriz que a representa) é surda. E quando Krasinski transpõe a narrativa para o ponto de vista dela, Um lugar silencioso tenta atingir o máximo que o cinema permite em termos de silêncio total.

\footnotetext{
${ }^{5}$ Sigla utilizada para designar a Língua de Sinais Americana, do inglês American Sign Language.
} 
Os filmes citados, assim como outros que escolhem expressar suas motivações e questionamentos por meio do silêncio, apresentam algo em comum: a resistência em limitar o cinema da contemporaneidade à aglomeração de imagens regidas por falas. A abertura proporcionada pelo silêncio à qual Forain (2013) se refere não é apenas interpretativa ou simbólica. Ela pode ser, também, a possibilidade de resgatar outros componentes da linguagem cinematográfica capazes de estabelecer uma conexão entre obra e espectador, sendo a trilha musical uma delas.

\subsection{A MÚSICA DOS FILMES}

Quando o som chega ao cinema, os filmes não passam a ser apenas falados. Como lembram Bordwell e Thompson (2001), além do discurso (narração, diálogos), são incorporados também outros elementos sonoros, como o ruído e a música. De forma geral, os sons presentes em um filme podem ser categorizados em diegéticos e não diegéticos: os diegéticos compreendem tudo aquilo que é passível de ser ouvido pelas personagens dentro de cena, seja uma conversa paralela em um bar, a música de fundo em uma festa, os latidos de um cachorro ou os automóveis passando na rua.

Os não diegéticos ou extradiegéticos, por sua vez, englobam os sons que, muito embora não sejam audíveis pelas personagens em cena, desempenham um papel importante na compreensão da narrativa, tais como a voz over (narração) e a trilha musical. Ainda é admitida uma terceira classificação para os sons na obra cinematográfica, chamada de meta diegética ${ }^{6}$. Esta categoria, de caráter subjetivo, abrange os sons que remetem ao imaginário ou às lembranças de uma personagem, seja em um sonho, alucinação ou até um flashback.

Como um dos objetivos da pesquisa é entender a relação da trilha musical com momentos de silenciamento verbal e incomunicação das personagens em Embriagado de amor e Sangue negro, este tópico será dedicado às funções da música nos filmes. Comumente, o termo "trilha sonora" é empregado para fazer menção às composições musicais dos mais variados produtos audiovisuais, desde novelas e séries de televisão até o cinema. Entretanto, na trilha sonora também

6 BARBOSA, Álvaro. O Som em Ficção Cinematográfica. 2000/01. Disponível em: <http://www.abarbosa.org/docs/som_para_ficcao.pdf>. Acesso em: 19 mai. 2018. 
estão contidos os efeitos sonoros e os diálogos. Dessa forma, ao referir-se especificamente às músicas, é mais apropriado utilizar a expressão "trilha musical"7.

Além de contribuir como um estímulo emocional, a música na obra audiovisual geralmente estabelece uma conversa com o enredo, proporcionando aos espectadores a noção de continuidade narrativa. Essa coerência pode ser representada de diversas maneiras: por meio de letras de canções que remetem ao momento mostrado em cena, pela intensificação ou diminuição da cadência de acordo com os acontecimentos, e até pela supressão desses sons.

Em relação às letras das canções, os musicais são um bom exemplo de como essa atribuição é empregada. As músicas desses filmes são criadas justamente para explicar situações ou descrever a condição emocional de uma personagem. E, enquanto elementos capazes de exprimir tais contextos, essas canções produzem uma continuação narrativa, fazendo-se necessárias para que a história seja compreendida. O mais interessante, nesse caso, é que as canções dos musicais existem tanto na diegese quanto no espaço extradiegético, já que são cantadas e percebidas pelas personagens e compõem, simultaneamente, a trilha musical.

Ainda sobre essa continuidade, André Baptista (2007, p. 58) afirma:

\begin{abstract}
Como a música é o som organizado no tempo, sua organização auxilia a conectar eventos díspares em outros domínios. Uma interrupção na música pode sinalizar uma mudança na narrativa. A música contínua pode também indicar a continuidade do tema corrente. Funcionando como um tipo de "cola", a música vai aglutinar os eventos multimidia de diferentes domínios em uma só direção, ajudando o cérebro - que tem uma capacidade limitada de seguir eventos - a "acompanhar a corrente". A função de continuidade ou interrupção da ação é uma técnica comum da composição musical para filmes. $^{8}$
\end{abstract}

Há, contudo, outros aspectos importantes que auxiliam no entendimento das funções da trilha musical nos filmes, tais como: o papel subjetivo exercido pela música, a comunicação de informações e a relação entre música e diálogo. Para Chion (1994), quando os diálogos são suprimidos ou a personagem encontra-se em um estado de subjetividade (reflexão, sonho, lembrança), a música reforça esses

\footnotetext{
${ }^{7}$ ALVES, Bernardo Marquez. Trilha Sonora: o cinema e seus sons. Revista Novos Olhares, São Paulo, Vol. 1 N. 2, pág. 90-95, $2^{\circ}$ semestre de 2012. Disponível em: <https://www.revistas.usp.br/novosolhares/article/viewFile/55404/59008>. Acesso em: 19 mai. 2018.

${ }^{8}$ BAPTISTA, André. Funções da música no cinema - contribuições para a elaboração de estratégias composicionais. Dissertação de Mestrado (Música e Tecnologia). Universidade Federal de Minas Gerais I Escola de Música, Belo Horizonte, 2007. Disponível em: <http://www.musica.ufmg.br/sfreire/depot/DISSANDREBAPT.pdf>. Acesso em: 19 mai. 2018.
} 
momentos. A presença do acompanhamento sonoro em consonância com a composição visual dá ênfase à mensagem e aos sentimentos pretendidos pelo realizador.

Annabel J. Cohen (1998), por sua vez, teoriza acerca da música como elemento condutor de informação. Por exemplo, dificilmente, a trilha musical de um filme do gênero terror terá elementos similares àqueles presentes na trilha de uma comédia. A partir dessa simples observação, é possível categorizar a qual gênero cinematográfico pertence determinado filme apenas ao ouvir suas músicas. Esse seria um primeiro nível de informação fornecido pela trilha.

No campo emocional, essa comunicação se dá, várias vezes, pela cadência da música. Cenas que expressam tristeza geralmente são acompanhadas por melodias mais lentas, enquanto momentos de felicidade tendem a possuir uma trilha mais dinâmica, com músicas rápidas. Essas informações não só complementam a narrativa (a já exposta continuidade) como também guiam as reações do espectador durante a projeção.

Ao falar sobre a música e os diálogos, Baptista (2007) apresenta situações que contribuem para uma melhor percepção desse vínculo. O autor ressalta que é necessário haver uma disposição equilibrada dos dois recursos, para que a autonomia de ambos seja conservada e, assim, eles possam exercer suas funções plenamente. Ele destaca, contudo, que há a "possibilidade de controlar o grau de independência entre diálogos e melodia" (2007, p. 104). Nessa situação, é imprescindível decidir qual dos elementos tem a habilidade de melhor expressar os sentidos da cena. Sendo a música, o silêncio nos diálogos é um das principais formas de transpor a importância para a trilha.

Baptista ainda enfatiza que, se a música e os diálogos não estiverem em sincronia, a comunicação ficará prejudicada, impedindo a compreensão da informação a ser transmitida. Ele lembra que não deve haver concorrência entre esses sons; eles precisam agir de forma integrada.

Dadas essas características, não há surpresa em constatar a importância que as trilhas musicais possuem para as obras cinematográficas. Não são poucos os exemplos em que as músicas encontram-se tão presentes no imaginário popular quanto os filmes aos quais correspondem. Existem alguns casos que podem ser citados para ilustrar esta afirmação, tais como a composição de Bernard Herrmann 
para Psicose (Psycho, 1960), de Alfred Hitchcock, eternizada na famosa cena do banheiro; as contribuições do compositor John Williams para Tubarão (Jaws, 1975) e as franquias Indiana Jones e Jurassic Park, de Steven Spielberg; a música-tema do Super-Homem em Superman: O filme (Superman, 1978) e de Darth Vader nos filmes Star Wars, também compostas por Williams; ou até a trilha musical de Vangelis para Carruagens de fogo (Chariots of fire, 1981), com direção de Hugh Hudson.

Porém, não apenas músicas instrumentais conseguem atingir esse resultado. Muitas canções tornaram-se conhecidas pelo grande público por meio dos filmes e, consequentemente, deram notoriedade aos seus cantores. My heart will go on, interpretada por Celine Dion e presente na trilha musical de Titanic (Titanic, 1997), permaneceu durante 20 semanas na parada da Billboard, alcançando o primeiro lugar por duas semanas consecutivas ${ }^{9}$. Cinco anos antes, em 1992, I will always love you, música-tema de O Guarda-costas (The bodyguard, 1992), cantada por Whitney Houston, foi a número 1 na parada da Billboard por 14 semanas, tendo permanecido na lista das 100 músicas mais tocadas ao longo de 29 semanas $^{10}$.

Todos esses exemplos demonstram como trilhas musicais, e os sons em geral, são eficazes em produzir emoções e gerar identificação do espectador com o filme. No entanto, o recurso deve construir uma relação simbiótica com as imagens. Isso não significa que a música precisa ser redundante ou apenas explanatória, mas que, som e imagem, dentro de seus domínios e com a devida independência, narrem a mesma história.

Quando aplicados esses aspectos aos objetos do trabalho, e à filmografia de Paul Thomas Anderson como um todo, é possível perceber que o diretor utiliza tais dispositivos de maneira recorrente. Dessa forma, as trilhas musicais nos filmes de Anderson pretendem não só dar continuidade e complementar o enredo, como também suscitar o estado emocional das personagens, relacionando-se de maneira íntima com os diálogos - ou a falta deles.

Além do mais, as personagens de Anderson frequentemente são pessoas com poucas habilidades sociais, o que resulta em uma dificuldade de comunicação.

\footnotetext{
9 Celine Dion chart history. Disponível em: <https://www.billboard.com/music/Celine-Dion/charthistory/hot-100/song/54234>. Acesso em: 19 mai. 2018.

10 Whitney Houston chart history. Disponivel em: <https://www.billboard.com/music/whitneyhouston/chart-history/hot-100/song/15629>. Acesso em: 19 mai. 2018.
} 
Assim, a trilha musical atua como um suporte à incomunicabilidade dessas personagens, fazendo com que elas, de alguma forma, se façam entender. Já que, agindo em concordância com os acontecimentos da trama, a trilha passa as informações necessárias ao espectador para a apreensão dos sentidos ali presentes.

\subsection{OS CAMINHOS DA INCOMUNICAÇÃO NO CINEMA}

O avanço constante da tecnologia no campo das telecomunicações tem possibilitado o estreitamento das relações sociais, sejam elas afetivas ou profissionais. Entrevistas de emprego podem ser realizadas por aplicativos e softwares de troca de mensagens que suportam chamadas de vídeo, enquanto conhecer pessoas que estão do outro lado do mundo requer apenas uma conexão com a internet. As distâncias geográficas são encurtadas pelas facilidades que a tecnologia proporciona, e o contato com outras culturas, sem a necessidade de deslocamento, nunca foi tão acessível.

O cenário descrito acima representa uma ideia de uma sociedade cada vez mais interligada, onde a troca de experiências é estimulada e as pessoas estão se tornando cada vez mais próximas. Contudo, há estudos ${ }^{11}$ que apontam o contrário: o uso cada vez mais intenso de mecanismos que têm a função de aproximar pessoas, as chamadas redes sociais, contribui para o aumento do isolamento social e, em casos mais severos, leva à depressão.

Norval Baitello Junior (2005), ao falar especificamente sobre a incomunicação humana, também identificou tal fenômeno. O autor afirma que na medida em que são criadas novas possibilidades de comunicação advindas da tecnologia, o homem, em igual proporção, também cria impedimentos para esse mesmo processo. Para Baitello, o território da incomunicação encontra-se em expansão, pois a capacidade do homem em se autoboicotar, produzindo lacunas em suas relações sociais, nunca esteve tão evidente.

Baitello coloca a comunicação como a construção dos vínculos firmados em sociedade, a interação entre as pessoas. Porém, o autor pontua que esses laços

\footnotetext{
${ }^{11}$ Social Media Use and Perceived Social Isolation Among Young Adults in the U.S. Disponível em: <https://www.ajpmonline.org/article/S0749-3797(17)30016-8/fulltext>. Acesso em: 31 mai. 2018.
} 
devem possuir um limite, pois o excesso de conhecimento do outro é um meio para a incomunicação. Ao pensar na questão da tecnologia, esse excesso se apresenta como o bombardeio de informações diárias às quais um usuário de redes sociais, por exemplo, está sujeito. É possível saber praticamente tudo sobre a vida de alguém ao acessar seu perfil em uma dessas mídias digitais. Sendo assim, é muito fácil construir uma percepção artificial de intimidade e, consequentemente, inferir que já não há mais nada a ser descoberto sobre o outro. Essa atitude gera aberturas para a incomunicação.

Atualmente, as relações virtuais sequer chegam a se atualizar no real, e os vínculos se restringem à rede, intermediados por avatares. Com estímulos como popularidade online instantânea, os indivíduos têm dedicado muito de seu tempo ao gerenciamento de suas contas em redes sociais, cortesia de celulares avançados que permitem conexão rápida com a internet em praticamente qualquer local. Isso faz com que as relações interpessoais presenciais se tornem cada vez mais escassas, ampliando a sensação de solidão.

Sobre isso, Baitello (2011, p.8) diz:

\begin{abstract}
Assim, todo vínculo não se sustentará quando não houver a intersecção de universos, de espaços físicos ou simbólicos. 'Comunicar' significa criar um espaço/tempo comum e colocar-se dentro dele. Ora o espaço comum se constrói com a somatória dos espaços individuais. Assim também o tempo comum. Se não temos espaço, se somos apenas o retrato, a imagem de um espaço, não será possível senão uma aproximação tangencial, um contato entre superfícies, sem aprofundamentos. ${ }^{12}$
\end{abstract}

A tríade incomunicação, solidão e tecnologia já vem sendo explorada há algum tempo nas produções audiovisuais. E, muito embora a questão da tecnologia não esteja presente nos filmes de Paul Thomas Anderson, é possível traçar uma relação entre suas personagens que possuem problemas de comunicação com aquelas de filmes que abordam o tema pelo viés tecnológico. Nesse caso, a solidão é o denominador comum entre elas e, por vezes, o gatilho da incomunicabilidade.

Primeiramente, contudo, é necessário esclarecer que a incomunicação tratada aqui diz respeito, sobretudo, à inaptidão em se comunicar propriamente advinda do desajuste social. De tal forma, e dentro do universo cinematográfico, ela

12 BAITELLO JR, Norval. Incomunicação e Imagem. Disponível em: $<$ http://www.cisc.org.br/portal/jdownloads/BAITELLO\%20JUNIOR\%20Norval/incomunicao_e_imagem. pdf>. Acesso em: 31 mai. 2018. 
faz alusão a personagens que possuem dificuldades em estabelecer vínculos com as demais pessoas e constroem relações truncadas. Isso não significa, no entanto, que essas mesmas personagens não estejam à procura de uma conexão emocional com outro indivíduo ou até consigo mesmas, principalmente como forma de aplacar a solidão na qual se encontram.

Alguns exemplos de como o cinema tem levantado o debate sobre o tema são os filmes Medianeras: Buenos Aires na era do amor virtual (Medianeras, 2011) e Ela (Her, 2013). Ambos trazem uma reflexão sobre as complicadas relações amorosas na contemporaneidade, especialmente aquelas travadas no ambiente online. As duas produções fazem um retrato da solidão nas grandes cidades, ressaltando a contradição vivida atualmente na qual, mesmo com os inúmeros dispositivos de comunicação disponíveis, as pessoas vêm se isolando progressivamente umas das outras.

Não é raro encontrar outros casos no cinema em que incomunicação e solidão aparecem juntas, mesmo quando não são mediadas pela tecnologia. Um bom exemplo é a Trilogia da Incomunicabilidade, do diretor italiano Michelangelo Antonioni, formada pelos filmes $A$ aventura (L'avventura, 1960), A noite (La notte, 1961) e O eclipse (L'eclisse, 1962). Nas obras, Antonioni explora personagens que, mesmo tentando, não conseguem se comunicar em um nível emocional com os outros. A vontade de encontrar uma conexão humana permeia as três obras, mas o ciclo não se faz completo porque as personagens estão consumidas pela própria solidão. Como Antonioni constrói as três narrativas em torno de relacionamentos amorosos, o peso dado a esse isolamento torna-se ainda mais expressivo.

Em O deserto vermelho (Il deserto rosso, 1964), Antonioni retorna aos temas, dessa vez tensionados também pela atmosfera visual criada pelo diretor. $O$ cenário industrial, cinza, carregado de neblina, enfatiza um ambiente de toxicidade que reflete a crise existencial de suas personagens, a inabilidade de compreensão que têm de si próprias e dos demais. Além disso, as longas cenas sem diálogos ajudam a realçar a palpabilidade do sentimento de incomunicação confeccionado por Antonioni.

Outro filme que envereda pelos mesmos temas é Paris, Texas (Paris, Texas, 1984), de Wim Wenders. A narrativa do diretor alemão conta a história de um homem, Travis (Harry Dean Stanton), que é apresentado ao espectador vagando 
sozinho, sem memória, no meio do deserto. A aridez das imagens iniciais conectase com o estado emocional de Travis: estéril. Mesmo à medida que recobra suas lembranças, Travis tem dificuldades em se expressar e assimilar os laços familiares que possui. Ao final, percebe-se que não há muitas diferenças entre o homem desmemoriado e aquele que já recuperou as recordações, pois ambos são marcados pela solidão e inabilidade em se comunicar.

A incomunicação também pode se apresentar como consequência do sentimento de não pertencer a determinado meio ou lugar. Ainda que nesses casos esteja atrelada à solidão, o foco principal é sanar o conflito que gera este estado de não pertencimento. Exemplo desse tipo de incomunicação no cinema é o filme $\mathrm{Na}$ natureza selvagem (Into the wild, 2007), de Sean Penn, em que a personagem principal, Christopher (Emile Hirsch), encontra obstáculos para criar vínculos com aqueles que fazem parte do seu meio social abastado.

Isso se dá pelo fato de Christopher repudiar o estilo de vida de seus pais e colegas, não se identificando com os códigos e valores que transpõem essas relações. Quando decide abrir mão de seus privilégios, Christopher renuncia ao próprio nome, extirpando os laços que o uniam à vida anterior, entendendo que só assim será capaz de encontrar seu lugar no mundo.

Todavia, vale pontuar que nem sempre a incomunicabilidade será representada pela ausência de diálogos. Esse é apenas um dos meios possíveis para dar transparência à questão. É possível existir falta de comunicação, também, quando há excesso de fala. Diante disso, a incomunicação seria traduzida pela inaptidão em ouvir, em ocupar-se tanto de si mesmo e não ser capaz de gerar empatia com o próximo. Alguns filmes de Woody Allen possuem essa característica. As personagens muitas vezes estão engajadas em diálogos longos, nos quais falam mais para si do que para a outra pessoa.

Certamente existem diversos outros exemplos que mostram a maneira como o cinema faz da incomunicação um tema recorrente. Estes filmes são, geralmente, voltados para o interior das personagens, preocupando-se com seus sentimentos e conflitos existenciais. Porém, mais do que tudo, fica clara nessas obras a intenção de evidenciar a fragilidade das relações humanas. 


\subsection{MÉTODO DE PESQUISA}

Além do aporte teórico-histórico, a presente pesquisa também apresenta faceta empírico-analítica, que tem como objetivo compreender as manifestações de silêncio verbal e incomunicação nos filmes Embriagado de amor e Sangue negro, do diretor Paul Thomas Anderson. A análise fílmica dessas duas obras é composta tanto pelos referenciais teóricos dos conceitos a serem observados, quanto pelo processo metodológico adotado, pois são eles que irão proporcionar o exame das informações colhidas dos objetos investigados.

A análise fílmica pode ser feita de diferentes formas, já que não existe uma metodologia única que a contemple. Porém, há um entendimento mais abrangente de que o sistema analítico é composto por dois aspectos: a decomposição, que se ocupa da descrição do objeto; e a interpretação, responsável por estabelecer uma correspondência entre os elementos resultantes da decomposição (VANOYE; GOLIOT-LÉTÉ, 2012). Mauro Giuntini (2015, p. 61), ao abordar o tema, comenta:

[...] é possível estabelecer conceitualmente as fundações desse processo analítico que consiste na desconstrução descritiva e na reconstrução interpretativa. Estabelecidas essas fundações, torna-se viável conceber análises em diferentes níveis - forma, conteúdo e relação de sons e imagens - para contemplar a narrativa cinematográfica como processo, representação e estrutura.

Ao acolher a desconstrução e a reconstrução como sistema de análise, é possível combiná-lo a outros métodos e, assim, obter resultados mais consistentes. Como, por exemplo, o processo cognitivo neoformalista de Bordwell e Thompson. 0 texto cinematográfico admite a existência de uma diferenciação nos significados de elementos de fácil identificação (aparentes) e aqueles que estão implícitos na mensagem do filme (ocultos). O reconhecimento desses sentidos, explícitos e velados, compreendem a descrição proposta por Vanoye e Goliot-Lété (2012). Enquanto a articulação dos dois adentra o campo da interpretação exposta pelos autores. 
Embora o cognitivismo neoformalista se posicione contrariamente ao processo interpretativo ${ }^{13}$, os dois modelos não precisam ser excludentes. $O$ neorformalismo admite a percepção global da obra por meio de suas características formais, tais quais fotografia, composição, montagem, música, entre outros. Esse tipo de análise possibilita uma compreensão ampla do objeto, além de ser flexível e adaptável a outras metodologia, pois é uma etapa cabível dentro do processo de desconstrução analítica. A combinação dos dois padrões foi crucial para determinar o sistema metodológico de análise a ser utilizado na pesquisa.

Dessa forma, foi adotado o seguinte procedimento para os dois filmes a serem estudados: a primeira etapa da análise consiste em ler os elementos constitutivos da narrativa como um todo, fazendo uma apresentação global das principais características que compõem as obras. Esta etapa combina os preceitos neoformalistas e a desconstrução fílmica. Nesta fase estão contidos os aspectos facilmente identificáveis das produções, que habitam a superfície do texto fílmico, como temáticas gerais e referências.

$\mathrm{Na}$ sequência, é realizada a reorganização das informações apreendidas no estágio de desconstrução, interpretando-as de maneira a perceber os sentidos e significados suscitados pelas obras e, assim, conectando as partes integrantes dos filmes. Aqui, há o aprofundamento nas questões-chave do trabalho: silêncio verbal e incomunicação. A pretensão proveniente da leitura realizada é saber qual o impacto desses elementos nas tramas e a maneira como interagem com outros componentes narrativos, como a trilha musical, por exemplo.

Todo esse processo, no entanto, não precisa ser feito de forma linear. Alternar durante as análises entre desconstruir/descrever e reconstruir/interpretar é uma maneira de conhecer ainda melhor o objeto. Com isso, é provável que não haja uma diferenciação clara das etapas no corpo do texto, pois elas podem coexistir sem comprometer a eficácia da análise. Porém, antes de iniciar efetivamente a análise dos filmes em questão, o segundo capítulo introduz o universo cinematográfico de Anderson. Tal ambientação visa proporcionar ao leitor um maior entendimento dos propósitos narrativos do diretor em Embriagado de amor e Sangue negro.

13 David Bordwell blows the whistle on film studies. Disponivel em: <http://www.davidbordwell.net/articles/Bordwell_Lingua\%20franca_vol10_no2_March2000_34.pdf>. Acesso em: 2 jun. 2018. 


\section{CAPÍTULO II}

\section{O UNIVERSO CINEMATOGRÁFICO DE PAUL THOMAS ANDERSON}

Este capítulo é dedicado a uma apresentação do trabalho realizado por Paul Thomas Anderson como diretor. No primeiro momento, são apresentadas algumas das características mais relevantes de sua obra, como as temáticas recorrentes em suas narrativas fílmicas. Também encontra-se aqui uma breve explanação sobre o modo como as questões do silêncio e da incomunicação, juntamente com a trilha musical, são exploradas em seus filmes.

$\mathrm{Na}$ sequência, o capítulo ocupa-se em discorrer acerca da construção das personagens de Anderson. Já o último ponto levantado diz respeito às influências cinematográficas do diretor e como ele lida com a intertextualidade em sua obra por meio de referências a outros cineastas. Em síntese, o propósito do capítulo é ambientar o leitor no universo cinematográfico de Anderson, proporcionando-lhe as informações necessárias antes de adentrar especificamente nas análises de Embriagado de amor e Sangue negro.

\subsection{OBRAS, CARACTERÍSTICAS E TEMÁTICAS ABORDADAS}

Responsável pela direção e roteiro de filmes aclamados pela crítica, tais como Magnólia (Magnolia, 1999) e O mestre (The master, 2012), Paul Thomas Anderson é um diretor de cinema estadunidense que ganhou visibilidade no meio cinematográfico em 1997 após o lançamento de Boogie nights - prazer sem limites. Além das obras já citadas, também são de autoria do diretor: Jogada de risco (Hard eight, 1996), Embriagado de amor, Sangue negro, Vício inerente (Inherent vice, 2014) e Trama fantasma (Phantom thread, 2017).

Desde 1997, Anderson também tem assinado a direção de videoclipes, colaborando ao longo dos anos com artistas como Fiona Apple. Aimee Mann, Radiohead e Haim, o que reforça a importância da música na trajetória do cineasta. Em 2015, Anderson dirigiu o documentário musical Junun (Junun, 2015), um making of do álbum homônimo que foi produzido por, entre outros músicos, Jonny 
Greenwood, guitarrista da banda Radiohead e compositor das trilhas musicais dos filmes de Anderson desde 2007.

Anderson pertence à leva de diretores revelados pelo Sundance Film Festival, importante festival de cinema independente dos Estados Unidos. Seu curtametragem Cigarettes and coffee (1993), que mais tarde daria origem ao longa Jogada de risco, foi exibido na mostra de curtas do evento e selecionado para participar do laboratório do Sundance, uma incubadora audiovisual de novos talentos. Alguns outros nomes que, igualmente a Anderson, despontaram em Sundance e alcançaram sucesso comercial e de crítica foram: os Irmãos Coen, Quentin Tarantino, Darren Aronofsky, Wes Anderson, David O. Russell e Richard Linklater. Atualmente, estes cineastas que surgiram da cena independente são considerados responsáveis pela renovação do cinema nos Estados Unidos.

Desde o seu primeiro filme, Jogada de risco, até a mais recente produção, Trama fantasma, Anderson adotou como um de seus principais centros temáticos as complexas relações familiares do final do século $X X$ e primórdios do XXI. De maneira mais objetiva, o diretor aborda este assunto ressaltando as percepções simbólicas da figura masculina na sociedade estadunidense, com foco especial na figura paterna, seja ela biológica ou figurativa (SPERB, 2013).

Consumidor ávido de produtos cinematográficos e televisivos durante a infância e a adolescência, entre as décadas de 1970 e 1980, entrevistas e artigos sobre o cineasta revelam que essas produções desempenharam uma grande influência em relação aos conteúdos presentes em seus filmes. No livro Blossoms and Blood (2013), o autor Jason Sperb pontua que, no decorrer dos anos 80, alguns dos filmes mais populares de Hollywood contavam histórias de núcleos familiares disfuncionais, não sendo, então, uma coincidência que o tema seja tão marcante na obra de Anderson. Isto se torna ainda mais evidente quando constatado o fato de que a ligação amorosa existente entre pai e filho exerce maior impacto nas narrativas do diretor do que uma possível relação amorosa entre homem e mulher (SPERB, 2013).

Este aspecto dos filmes de Anderson acarreta algumas críticas ao seu trabalho, sobretudo no que se refere à representação dedicada às mulheres. $O$ destaque conferido à busca por uma figura masculina dominante e a dinâmica travada por pais e filhos não deixam, na maioria das vezes, espaço para um 
desenvolvimento mais acurado das personagens femininas (SPERB, 2013). E, quando Anderson se ocupa em explorar esse universo com maior afinco, não são raros os momentos em que ele retrata mulheres como as principais causadoras de angústia ou seres que tentam diminuir de alguma forma a masculinidade do protagonista homem (SPERB, 2013), como acontece abertamente com a mãe de Dirk em Boogie nights - prazer sem limites e as irmãs de Barry em Embriagado de amor.

Entretanto, Anderson discorre sobre uma vasta série de temas, não ficando restrito apenas às questões masculina e familiar. Também são de interesse do diretor explorar tópicos como alienação, cultura de consumo, midiatização social e as interferências do acaso na vida das pessoas (SPERB, 2013). Estas interferências, em especial, denotam a construção de tramas permeadas pela aleatoriedade, onde, muitas vezes, não é possível perceber claramente a conexão entre causa e efeito.

Sperb associa a propensão do diretor em solucionar os conflitos de suas narrativas a partir de eventos randômicos à tentativa de encontrar alguma ordem na atmosfera caótica que ele mesmo arquiteta. Exemplos dessa inclinação de Anderson são a chuva de sapos ao final de Magnólia: um acontecimento inusitado, sem qualquer vínculo com a história, mas que proporciona uma amarração dos conflitos apresentados ao longo da trama; e o harmônio de Barry em Embriagado de amor, já que o instrumento surge de forma imprevisível e passa a atuar como um elemento apaziguador para a confusão da personagem.

Outras características comuns nas obras de Anderson são a composição de personagens marcadas pela solidão e pela incapacidade em se comunicar, independentemente da temática abordada. Estes traços determinantes na construção das personagens ficam mais evidentes em Embriagado de amor (solidão e incomunicação) e Sangue negro (solidão e silêncio), obras que serão analisadas nos capítulos III e IV.

Quando uma personagem de Anderson se cala ou não consegue se expressar devidamente, a mudez e a inabilidade de comunicação transcendem o corpóreo. Não é apenas a boca que se fecha, ou as cordas vocais que não emitem um som reconhecível, é a formação de um vazio espiritual inquietante, que evidencia a ansiedade e o desespero vividos pelas personagens. Em contraponto, todo o resto 
grita: olhos, mãos, movimentos. Essa ideia de transfiguração comportamental advinda do silêncio também é debatida por Orlandi. A autora afirma que "quando alguém se pega em silêncio, rearranja-se, muda a 'expressão', os gestos. Procura ter uma expressão que 'fala'" (2011, p. 34).

Vale pontuar que o silenciamento verbal e a falta de habilidade na comunicação estão diretamente relacionados nos filmes do diretor. O silêncio de Anderson é constituído pela ausência de verbalização ou incoerência na articulação de diálogos coerentes, e não na supressão de outros sons incidentais ou diegéticos. Até porque, para compreender de modo mais claro os propósitos narrativos de Paul Thomas Anderson ao servir-se do silenciamento verbal ou da incomunicação em seus filmes, é preciso levar em consideração a importância do elemento musical para as tramas. Isso porque as trilhas musicais, não raramente, reforçam as condições psíquicas e emocionais das personagens, frequentemente caóticas.

Mesmo com uma análise superficial, é possível notar que as músicas presentes nos filmes de Anderson se destacam na complementação de aspectos específicos das narrativas. Isto pode ser observado, por exemplo, na sequência em que Dirk Diggler (Mark Wahlberg) e seus amigos, Reed (John C. Reilly) e Todd (Thomas Jane), tentam fornecer cocaína de má qualidade para o violento traficante Rahad Jackson (Alfred Molina) em Boogie nights. O desenho da cena e o comportamento dos atores sugerem que a situação não terá um desfecho favorável, mas o presságio de desastre iminente é acentuado, sobretudo, pela presença da canção Jessie's Girl, cuja letra fala sobre amigos que se tornam rivais por motivos de cobiça e inveja.

Em Magnólia há duas passagens emblemáticas no que concerne ao uso da música como elemento-chave. A primeira acontece logo na abertura do filme, quando os protagonistas, solitários e abandonados ao seu próprio modo, são introduzidos ao som de One, de Aimee Mann, que fala de perda e solidão. A segunda se encontra mais ao fim do filme, em um momento que representa o ápice da angústia vivida pelas personagens. Os protagonistas externam essa dor cantando, separados mas simultaneamente, a mesma música, Wise Up, também de Mann, sobre frustrações e dissabores da vida. A partir dos exemplos de Boogie nights e Magnólia, percebe-se que, mais do que o momento oportuno de inserção musical, as letras das músicas também podem trazer aspectos que, dependendo da 
situação, reforçam e ressignificam o silêncio e a falta de comunicação das personagens.

Segundo Santiago Kovadloff, "a música oferece ao homem um espelho onde, ao se contemplar, pode reconhecer-se invisível" (2003, p. 68). De tal modo, o silêncio pretende romper com essa invisibilidade e forçar esse mesmo homem a enxergar-se com todas as suas idiossincrasias. O autor ainda declara que "entre a índole do não enunciável e a trama musical existe uma misteriosa correspondência" (KOVADLOFF, 2003, p. 64), algo perceptível nos filmes de Anderson em relação à música. Principalmente porque, muitas vezes, as letras das canções em suas produções intensificam a atribuição de sentidos sugeridos pela cena, além de funcionarem como um recurso de preenchimento das lacunas deixadas por diálogos incompletos.

Nesse ponto, existe uma aproximação entre Anderson e o cineasta Stanley Kubrick. Dentre outras características técnicas, Kubrick é reconhecido por transmitir sentido em suas narrativas suprimindo regularmente os diálogos para dar ênfase às composições visual e sonora. Ou seja, nos filmes de Kubrick, o espectador não necessita que uma ideia seja verbalmente expressa para que o seu significado possa ser compreendido (DUNCAN, 2013).

Um bom exemplo na obra de Kubrick dessa capacidade de transmitir uma ideia sem a explicitação da fala está em 2001: Uma odisseia no espaço. Na sequência em que Hal 9000, um computador, lê os lábios de David (Keir Dullea) e Frank (Gary Lockwood), o som da fala das personagens é omitido. A transição de câmeras e a crescente tensão da trilha demonstram que Hal e o espectador são capazes de compreender o teor da conversa entre os astronautas. Trata-se de informação primordial para o entendimento da trama: desligamento de Hal. Tal informação repercute em uma mudança de comportamento por parte do computador, fazendo com que ele assuma uma postura vingativa.

É possível notar a influência de Kubrick em Anderson também na abertura de Sangue negro, já citada anteriormente, na qual palavra alguma é proferida em uma sequência de 14 minutos. Porém, os acontecimentos dessa cena específica são responsáveis pelo desenrolar de toda a narrativa. A atmosfera confeccionada por Kubrick em torno do silenciamento verbal das personagens funciona como gatilhos emocionais para quem assiste a seus filmes (DUNCAN, 2013). E é nessa fonte que 
Anderson busca inspiração em suas estratégias narrativas de transmitir informações sobre a história por meio da trama minando o peso das palavras nos diálogos.

Existe uma ampla gama de exemplos que apontam a presença recorrente do silêncio verbal e da incomunicação nos filmes de Anderson. Todavia, tão relevante quanto identificar a existência desses temas na obra do diretor é entender como ele constrói suas personagens, conduz suas narrativas e trabalha com a intertextualidade ao fazer referência a diretores de cinema que o influenciaram artisticamente. Tais aspectos interferem diretamente na orquestração que Anderson promove entre silêncio, incomunicação e música, ao conferir densidade dramática aos seus filmes.

\subsection{CONSTRUÇÃO DE PERSONAGENS}

Ao lidar com temas como solidão e relações familiares, Paul Thomas Anderson construiu uma série de personagens socialmente desajustadas. No universo criado pelo diretor, as personagens são pessoas com profundos dramas internos, especialmente em relação ao sentimento de pertencer, seja a um lugar, meio ou alguém. O confronto que travam consigo próprias faz com que estejam sempre em busca de algum tipo de conexão, mas suas inabilidades, principalmente de comunicação, dificultam esse processo.

A consistência das personagens de Anderson reside nos paradoxos que possuem, já que a instabilidade emocional é uma marca que permeia praticamente todas elas. Como os filmes do diretor procuram representar as controvérsias da natureza humana, não há espanto na constatação de que seus heróis são falhos, imperfeitos. Sobre esse tipo de personagem, Linda Seger (1990, p.53, tradução nossa) diz:

Sendo a natureza humana o que é, uma personagem sempre é mais do que uma série de coerências. As pessoas são ilógicas e imprevisíveis. Elas sempre fazem coisas que nos surpreendem, que nos chocam, mudam todas as ideias preconcebidas que temos sobre elas. ${ }^{14}$

\footnotetext{
${ }^{14}$ No original: "Human nature being what it is, a character is always more than just a set of consistencies. People are illogical and unpredictable. They do things that surprise us, startle us, change all our preconceived ideas about them." (SEGER, 1990, p. 53).
} 
Existem algumas outras características que também são compartilhadas pelas personagens de Anderson. Uma delas é o fato de que as personagens frequentemente ingressam em um ciclo regido pelas leis do consumo (SPERB, 2013). Tal aspecto tem conexão direta com a pretensão de Anderson em refletir sua frustração cultural com uma sociedade materialista, que busca satisfação pessoal por meio da efemeridade contida no ato de possuir coisas (idem). Essa perspectiva também se relaciona com a questão da alienação em seus filmes, baseada em princípios culturais, históricos e econômicos (idem).

Um exemplo desse traço é a compulsão de Barry, em Embriagado de amor, para adquirir produtos cujos códigos de barras podem ser convertidos em milhas aéreas. Ao encontrar uma falha no sistema da promoção, o rapaz faz um estoque de pudins de chocolate mesmo sem ter intuito algum de viajar. Apenas a possibilidade de possuir algo, aliada à noção de um benefício em potencial, já são estímulos suficientes para justificar o consumo. Não é à toa, então, que as personagens nos filmes de Anderson possuem muitas coisas desnecessárias e dispensáveis.

Fora isso, outro ponto compartilhado pelas personagens é a força da ação do acaso e da coincidência nas suas vidas (SPERB, 2013). Esse elemento tem repercussão direta no desenvolvimento das narrativas de Anderson, pois é a partir dessas imprevisibilidades que o diretor urde algumas reviravoltas em suas tramas. $O$ desenrolar de acontecimentos conduzidos pela aleatoriedade aparece com mais força em Jogada de Risco, Magnólia e Embriagado de amor. Por vezes, estes filmes não atendem à noção tradicional de uma narrativa com causa e efeito, deixando a resolução de conflitos à mercê do destino.

$\mathrm{Na}$ introdução de Magnólia, uma narração em off conta diversas situações mirabolantes que, para uma análise lógica, seriam praticamente impossíveis de acontecer. No entanto, o narrador afirma que os fatos ali mostrados são perfeitamente plausíveis quando percebidos por meio da ação do acaso. Esta apresentação já indica que a trama de Magnólia é guiada por essas coincidências da vida. Muito embora estas coincidências sejam de difícil assimilação no início, elas são aceitas pelas personagens porque trazem respostas aos seus questionamentos internos, principalmente.

Contudo, o comprometimento de Anderson na construção multidimensional das personagens não impede uma tolerância com a inconsistência de alguns de 
seus protagonistas, o que afeta o andamento das tramas. Mesmo que a temática traga críticas socioculturais em seu subtexto, o diretor preserva algumas personagens, especialmente se forem masculinas. Certos deslizes e imperfeições dos homens nos filmes de Anderson são incorporados e justificáveis no universo dramático de seus filmes. Estas falhas das personagens têm consequências, mas tendem a demorar para se manifestarem.

A eventual complacência do diretor com algumas de suas personagens masculinas está presente sobretudo em Jogada de Risco, visto que as ações de todas as outras personagens parecem, de alguma maneira, estar sempre a serviço dos desejos de Sydney (Philip Baker Hall); e em Sangue negro, na imagem do protagonista Daniel Plainview, interpretado pelo ator Daniel Day-Lewis. Nos dois casos, as narrativas se desenrolam em função das verdades apregoadas por essas personagens, que gozam da indulgência de Anderson em relação a suas falhas de caráter. Tal característica, entretanto, não se aplica a filmes como Boogie nights e Magnólia, que contam com elencos extensos e homogeneamente desenvolvidos.

Outro traço importante na construção das personagens de Anderson é a relevância da busca de redenção em suas trajetórias. Comumente retratadas como pessoas emocionalmente desamparadas e consumidas pela culpa, as personagens de seus filmes procuram o perdão, inclusive o delas mesmas. Quando não atingem tal objetivo, são gradativamente corroídas pelos seus remorsos, caso de Jimmy Gator (Philip Baker Hall), em Magnólia, e Lancaster Dodd (Philip Seymour Hoffman), em O mestre.

Essas características fazem com que as personagens de Anderson sejam intensas e humanas. Algumas delas sequer são agradáveis, chegando até a causar incômodo, mas promovem identificação com o espectador por meio da humanidade que expressam. Além disso, Anderson também é hábil em empregar técnicas que acentuam as fragilidades das personagens, como a aproximação lenta da câmera em seus rostos.

Por vezes Anderson lança mão de algumas estratégias narrativas que fazem referência direta a cineastas que, de certa forma, influenciam seu trabalho. E dentre os diversos diretores já citados pelo próprio Anderson como sendo fontes de inspiração para seus filmes, os que mais se destacam são Robert Altman, Stanley Kubrick e Martin Scorsese. 


\subsection{INFLUÊNCIAS: ALTMAN, KUBRICK E SCORSESE}

Entre o final da década de 1690 e durante os anos 70, o cinema dos Estados Unidos testemunhou o surgimento de um novo movimento cinematográfico, denominado Nova Hollywood (BISKIND, 2009). Uma gama de jovens diretores procurou romper a tradição dos grandes estúdios e passou a produzir trabalhos que, tanto no conteúdo quanto na forma, diferenciavam-se dos filmes até então reverenciados pelo grande público (idem). Em muito, a ruptura proposta por esses cineastas assemelhava-se àquela adotada pela Nouvelle Vague $^{15}$, e tal qual os franceses, os norte-americanos buscavam reconhecimento pela sua genialidade criativa e autoralidade.

Os cineastas da Nova Hollywood priorizaram um cinema mais provocativo, que se distanciava de convenções formais como linearidade narrativa ou personagens com claras motivações (BISKIND, 2009). Ao invés de dedicarem-se aos épicos, musicais ou comédias românticas, principais produtos da Era de Ouro hollywoodiana, eles passaram a produzir filmes mais conectados com a realidade social do país. Assim, temas até então polêmicos em Hollywood tornaram-se pauta do movimento, como liberdade sexual, transtornos mentais, consumo de drogas e aumento da violência urbana (idem).

Não raramente, as produções da época traziam um tom de ironia e pessimismo, o que reforçava a descrença dos diretores não só em relação ao rumo tomado pelos Estados Unidos enquanto nação, mas com a própria indústria cinematográfica. Como as escolhas visuais dos cineastas também robusteciam o tom de crítica das produções, Hollywood viu seus clássicos esperançosos e multicoloridos serem substituídos por filmes ácidos e dessaturados. Em meio a esse cenário, ganham força nomes que, mais tarde, seriam consagrados grandes diretores do cinema mundial, a exemplo de Robert Altman, Stanley Kubrick e Martin Scorsese. Muitos outros fazem parte da lista, mas a importância dos três reside no

\footnotetext{
${ }^{15}$ Movimento de cinema francês da década de 1960, a Nouvelle Vague foi responsável pela redefinição de padrões estéticos e estilísticos que impactou a forma de fazer filmes em todo o mundo. Algumas de suas principais características são a ruptura com a narrativa clássica e a fragmentação da montagem. Dois dos maiores expoentes da Nouvelle Vague foram Jean-Luc Godard, diretor de Acossado (À bout de souffle, 1960) e François Truffaut, que dirigiu, entre outros sucessos do movimento, Os incompreendidos (Les quatre cents coups, 1959) (MASCARELLO, 2012).
} 
peso da influência que seus trabalhos possuem para a obra de Paul Thomas Anderson.

Antes de abordar o impacto desses diretores em Anderson, faz-se necessário, contudo, discorrer um pouco sobre como ele lida com a questão da intertextualidade. Em linhas gerais, a intertextualidade se apresenta como uma espécie de diálogo entre os textos de uma obra (ou obras) pré-existente e aquela que se propõe a referenciá-la, seja diretamente ou de forma velada $\left(\right.$ ZANI, 2003) ${ }^{16}$. No cinema, ela pode ser identificada desde o princípio, já que, quando da sua criação, a nova arte se apropriou de discursos vindos de outras expressões para compor sua linguagem. No caso de Anderson, a intertextualidade se manifesta nas referências às obras de diretores que o influenciaram, além de adaptação de algumas técnicas utilizadas por esses cineastas para compor seu próprio estilo.

De Altman, Anderson herdou, principalmente, a preferência pelos planossequência e os ensemble casts $^{17}$ (SPERB, 2013). Esses aspectos, bem como a descentralização narrativa típica de Altman, ficam muito evidentes em Boogie nights - prazer sem limites e Magnólia, fazendo referência direta a filmes como Nashville (Nashville, 1975) e Short cuts - cenas da vida (Short cuts, 1993).

Outro ponto de convergência entre Anderson e Altman é a tentativa de subversão das convenções narrativas de alguns gêneros cinematográficos. Nesse aspecto, a aproximação entre $O$ perigoso adeus (The long goodbye, Robert altman, 1973) e Vício inerente (Inherent vice, Paul Thomas Anderson, 2014) é quase inevitável, já que ambos buscam romper com as normas dos filmes de detetive, distanciando-se das fórmulas comumente aplicadas ao gênero.

Há ainda outros exemplos nesse campo: Altman tensiona em Popeye (Popeye, 1980) as convenções utilizadas nos musicais, enquanto Anderson conduz Embriagado de amor, uma comédia romântica, repleta de usos incomuns de músicas para o gênero. Não é coincidência, portanto, o fato da música He Needs Me também fazer parte da trilha de Embriagado de amor, já que a canção é interpretada por Olívia Palito (Shelley Duvall) no Popeye de Altman.

\footnotetext{
${ }^{16}$ ZANI, Ricardo. Intertextualidade: considerações em torno do dialogismo. Em Questão, v. 9, n. 1, p. 121 - 132. Porto Alegre, jan./jun. 2003. Disponível em: <http://seer.ufrgs.br/index.php/EmQuestao/article/viewFile/65/25>. Acesso em: 15. mai. 2018.

17 Expressão utilizada para determinar o conjunto de elenco de uma produção em que as personagens desenvolvem papéis igualmente importantes para a trama.
} 
$\mathrm{Na}$ introdução do livro Altman on Altman (2006), editado por David Thompson, Anderson (2006, I. 170-183, tradução nossa) assume a principal contribuição de Altman em sua obra:

\begin{abstract}
A partir do trabalho dele, eu comecei a perceber que não precisava das coisas que aprendi no manual "Como Fazer Filmes". A história não precisava conter lições ou uma moral; as coisas podiam ficar à deriva e as histórias podiam divagar e ser mais efetivas em capturar momentos de verdade do que indo direto ao ponto. Elas podiam ser longas, podiam ser musicais sem que houvesse alguém cantando, e podiam ser sujas e espertas ao mesmo tempo. Começos, meios e fins podiam fluir delicadamente sem uma ordem específica, sem nem precisar se tratar de um grande filme. As coisas podiam apenas acontecer sem explicação ou muita pompa, e os resultados falariam por si próprios. [...] A maioria de seus personagens são apenas pessoas tentando seguir em frente sem muito rebuliço. Os filmes de Bob me ensinaram a confiar que a coisa mais interessante - a única coisa interessante na tela - são as pessoas. ${ }^{18}$
\end{abstract}

Além de Altman, Anderson também assume a influência de Stanley Kubrick em seu trabalho por meio de citações em seus filmes. Na sequência de abertura de 2001, a trilha musical é parte da introdução do poema sinfônico Assim Falou Zaratustra, de Richard Strauss. A mesma composição é utilizada na primeira cena de impacto da personagem de Tom Cruise, Frank T. J. Mackey, em Magnólia. A homenagem a Kubrick é ainda mais significativa nesse caso porque Anderson conheceu Tom Cruise no set de filmagens de De olhos bem fechados (Eyes wide shut, 1999), último filme de Kubrick, lançado postumamente no mesmo ano de Magnólia.

Existem outras citações de Kubrick na obra de Anderson. De trabalhador de mina à magnata do petróleo, o sucesso de Daniel Plainview em Sangue negro é primeiramente afirmado pela importância que Anderson dá à cena em que a personagem assina o nome em um cheque indenizatório após seu acidente (figura 1). O dinheiro será utilizado para financiar o êxito comercial de Plainview no ramo petrolífero (SPERB, 2013).

\footnotetext{
${ }^{18}$ No original: "From his work, I began to realise that I didn't need any of the things l've learned from "How to Make Movies Book". There didn't have to be lessons or a moral to the story; things could drift in and out and stories could ramble and be more effective in glimpsing moments of truth rather than going to the touchdown. They could be long, they could be musicals without people singing, and they could be dirty and smart at the same time. Beginnings, middles and ends could all flow delicately together in any order, and weren't even needed to be a great film. Things could just happen without explanation or too much fanfare, and the results would take care of themselves. [...] Most of his characters are just folks trying to move along without too much fuss. Bob's films taught me to trust that the most interesting thing - the only interesting thing on screen - is the people." (THOMPSON, 2006, p.43).
} 


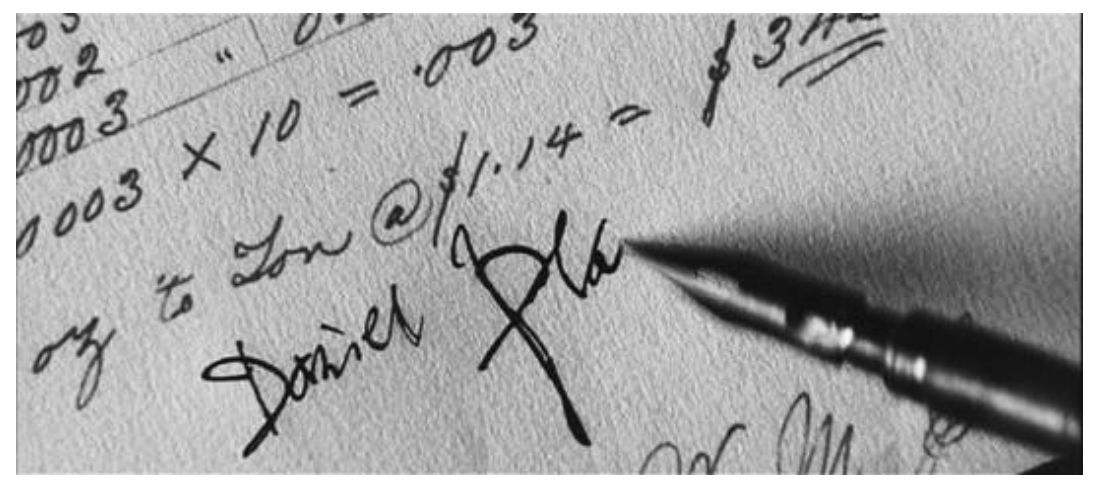

Figura 1 - Assinatura de Plainview mostrada pela primeira vez

A confiança de Plainview é traduzida pela firmeza na assinatura e a clareza com a qual seu nome pode ser lido. Próximo ao final do filme há outra cena em que é possível ver novamente a assinatura de Daniel (figura 2), mas agora borrada, sem a firmeza anterior.

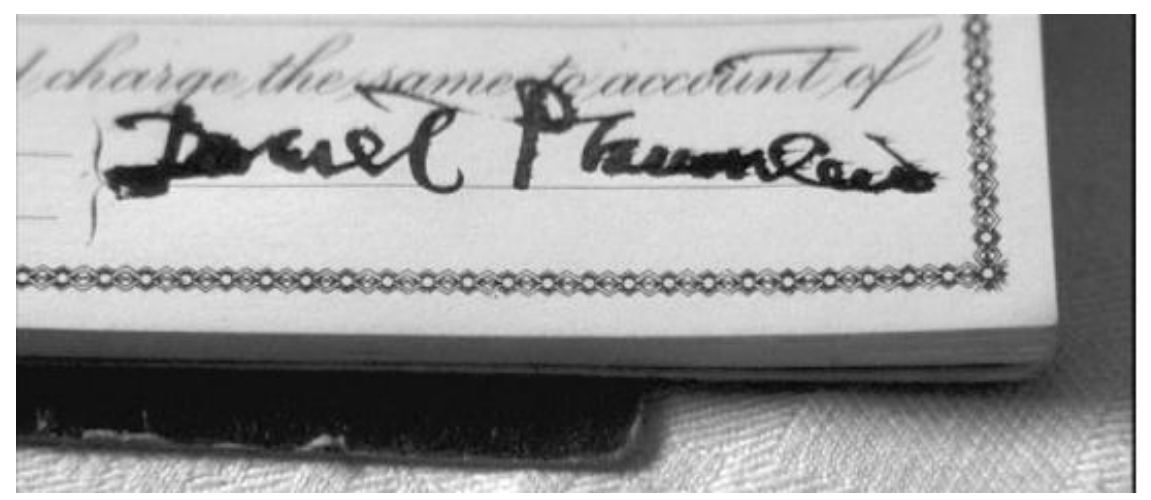

Figura 2 - Assinatura de Plainview mostrada já ao final do filme

Além de ressaltar a decadência da personagem na segunda cena, Anderson cita o fim de Barry Lyndon (Barry Lyndon, 1975), de Kubrick, no qual Lady Lyndon (Marisa Berenson), ex-esposa de Barry, mostra-se desinteressada ao assinar o cheque da pensão anual (figura 3) que paga ao ex-marido (SPERB, 2013). 


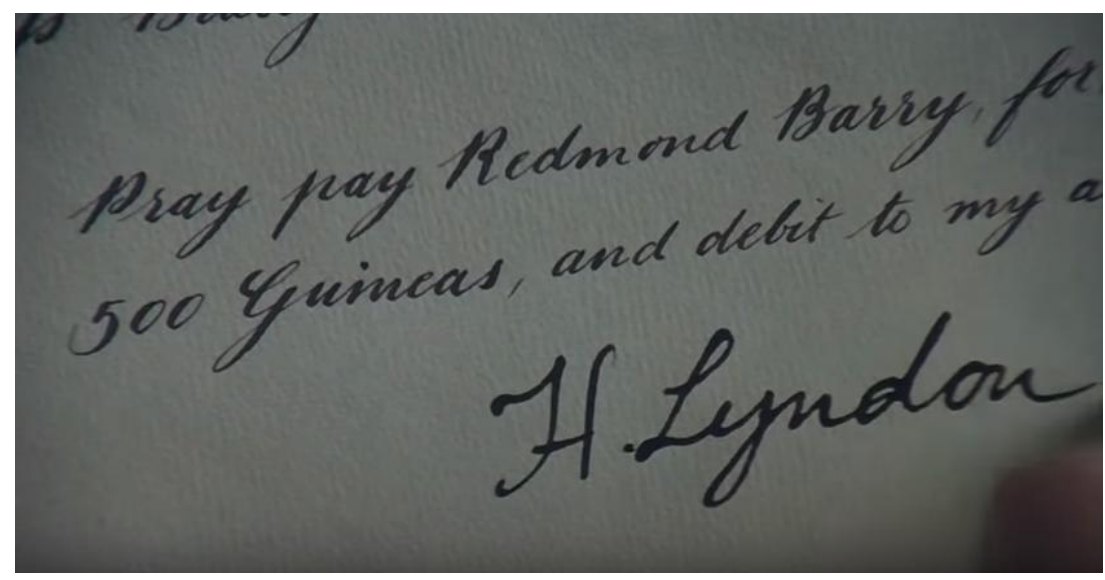

Figura 3 - Assinatura de Lady Lyndon no cheque anual para Barry

Tanto Plainview quanto Lyndon são de origem pobre, mas a ambição dos dois fez com conhecessem o dinheiro e poder. Ao término das narrativas, ambos foram derrotados pela própria arrogância e nada mais são do que nomes que aparecem displicentemente em cheques.

A presença de uma aura kubrickiana em Sangue negro foi muito comentada pela crítica após o lançamento do filme. A expressividade visual da obra, trilha inquietante e centralização em uma personagem solitária e emocionalmente isolada foram alguns dos principais pontos que levaram às comparações com Kubrick, mais especificamente com O iluminado (The shining, 1980). Sobre a relação entre os dois filmes, Sperb (2013, I. 3588-3603, tradução nossa) ressalta:

\begin{abstract}
Assim como o clássico do horror, Sangue negro é uma história de isolamento, de um homem confrontado pela indiferença da natureza apenas para descobrir que sua maior adversária é a insanidade - resultado direto das obsessões profissionais e laços familiares desintegrados. Plainview e Jack Torrance, de $O$ iluminado, são ambos monstros épicos que eventualmente se voltam contra seus respectivos filhos. [...] A tomada de Plainview com a picareta no interior da mina remete à tomada de Jack e seu machado do lado de fora da banheiro da família. A vastidão estéril da primeira tomada de Sangue negro relembra a abertura idêntica de $O$ iluminado [...] Finalmente, as tiras vermelhas nas paredes da pista de boliche evocam o elevador que transborda e inunda o corredor de sangue em O iluminado. ${ }^{19}$
\end{abstract}

\footnotetext{
${ }^{19}$ No original: "Like that horror classic, There Will Be Blood is a tory of isolation, of a man pitted against the indifference of nature only to discover his greatest adversary is encroaching insanity which is direct result of professional obsessions and disintegrating family ties. Plainview and The Shining's Jack Torrance are both larger-than-life monsters who eventually turn on their respective sons. [...] A shot of Plainview hacking away at the insides of a mine echoes the shot of Jack and his axe outside the family's bathroom. The barren wilderness of There Will Be Blood's first shot recalls an identical opening to The Shining [...] Finally, the deep red stripes along the wall of the bowling alley evoke The Shining's overflowing elevator and blood-soaked hallway." (SPERB, 2013, I. 3588-3603).
} 
Anderson também fez questão de filmar várias cenas de Sangue negro com luz natural, em especial a explosão (figura 4) que acontece durante a extração de petróleo na terra de Eli Sunday (Paul Dano).

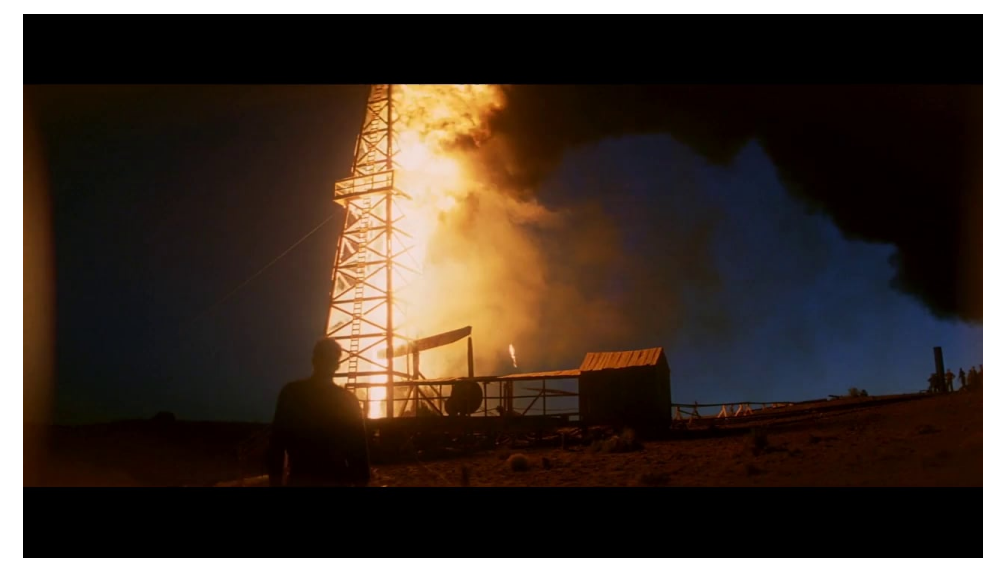

Figura 4 - Iluminação natural em Sangue negro

Com isso, o diretor buscou fazer alusão à atmosfera criada por Kubrick nas cenas de Barry Lyndon que foram capturadas apenas com a iluminação de velas ou fogueiras que compunham o cenário (figura 5).

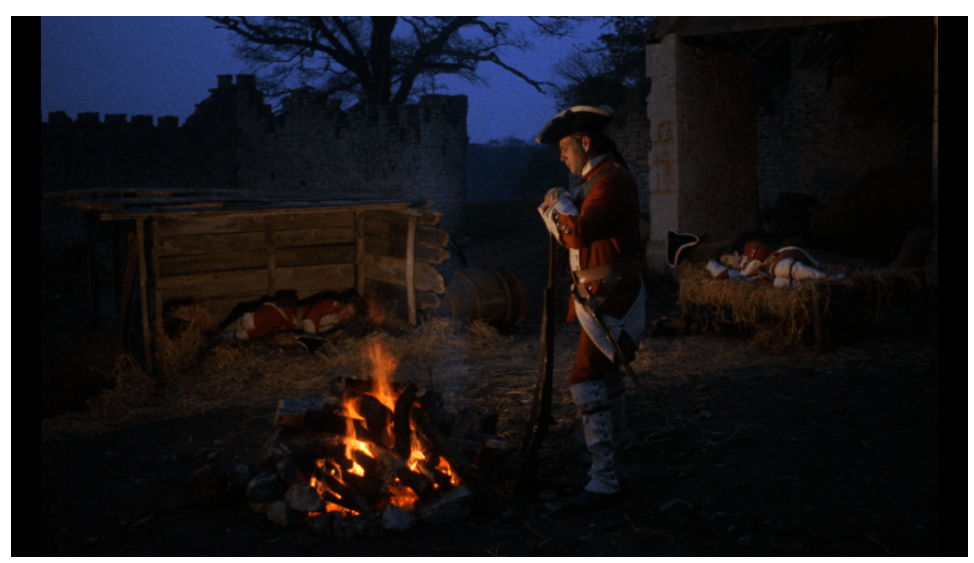

Figura 5 - Iluminação natural em Barry Lyndon

Da mesma forma como é influenciado por Altman e Kubrick, Paul Thomas Anderson encontra no cinema de Martin Scorsese uma fonte de inspiração. Em trabalhos mais recentes, como $O$ mestre ou Trama fantasma, Anderson tem conseguido inserir as referências a outros filmes e diretores de forma mais sutil, demonstrando seu amadurecimento profissional. Porém, no início da carreira, essas alusões eram bem mais perceptíveis, tanto que Boogie nights, mesmo bem-sucedido 
com a crítica, foi considerado a versão pornô de Os bons companheiros (Goodfellas, 1990), dirigido por Scorsese (SPERB, 2013).

Anderson explora em Boogie nights elementos muito similares àqueles utilizados por Scorsese em seu drama policial, sendo os raccords ${ }^{20}$ e a rápida movimentação de câmera os que mais se destacam (SPERB, 2013). Adepto das tracking shots ${ }^{21}$, Scorsese faz uso da técnica em um dos planos mais famosos de Os bons companheiros: a chegada de Henry Hill (Ray Liotta) ao clube Copacabana. Anderson emula a cena na abertura de Boogie nights, quando apresenta as personagens do filme com uma tracking shot filmada também em uma casa noturna.

Contudo, as referências a Scorsese presentes em Boogie nights não se restringem apenas a Os bons companheiros. É possível encontrar conexões diretas com Caminhos perigosos (Mean streets, 1973) e Touro indomável (Raging bull, 1980) também. De Caminhos perigosos, Anderson mimetiza em diversos momentos a ambientação da "cena vermelha" (figuras 6 e 7) de Charlie (Harvey Keitel) e Johnny Boy (Robert De Niro) em um bar.

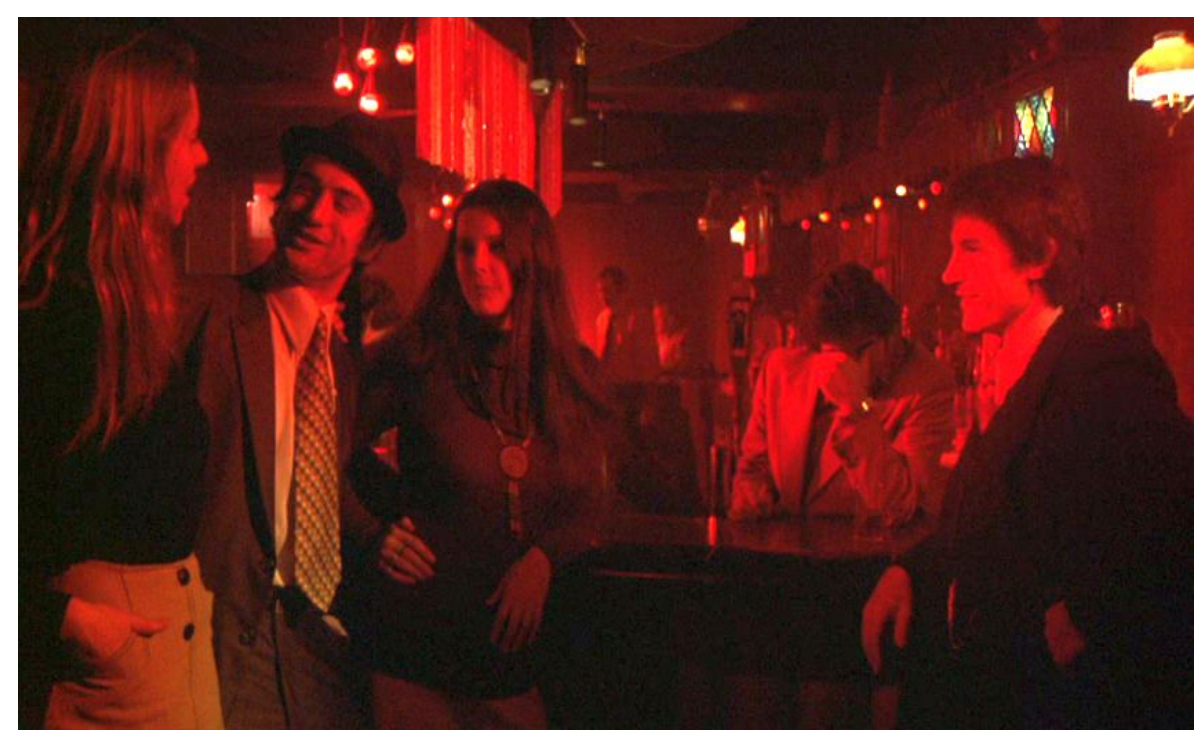

Figura 6 - Cena vermelha de Caminhos perigosos

\footnotetext{
20 "Tipo de montagem na qual as mudanças de planos são, tanto quanto possível, apagadas como tais, de maneira que o espectador possa conectar toda a sua atenção na continuidade da narrativa visual." AUMONT; MARIE, 2012).

${ }^{21}$ Movimento de câmera que segue paralelamente, pela frente ou por trás uma personagem ou veículo. A técnica é muito empregada para acompanhar um objeto que deixaria de aparecer no enquadramento da cena, sendo chamada também de following shot (BROWN, 2012).
} 


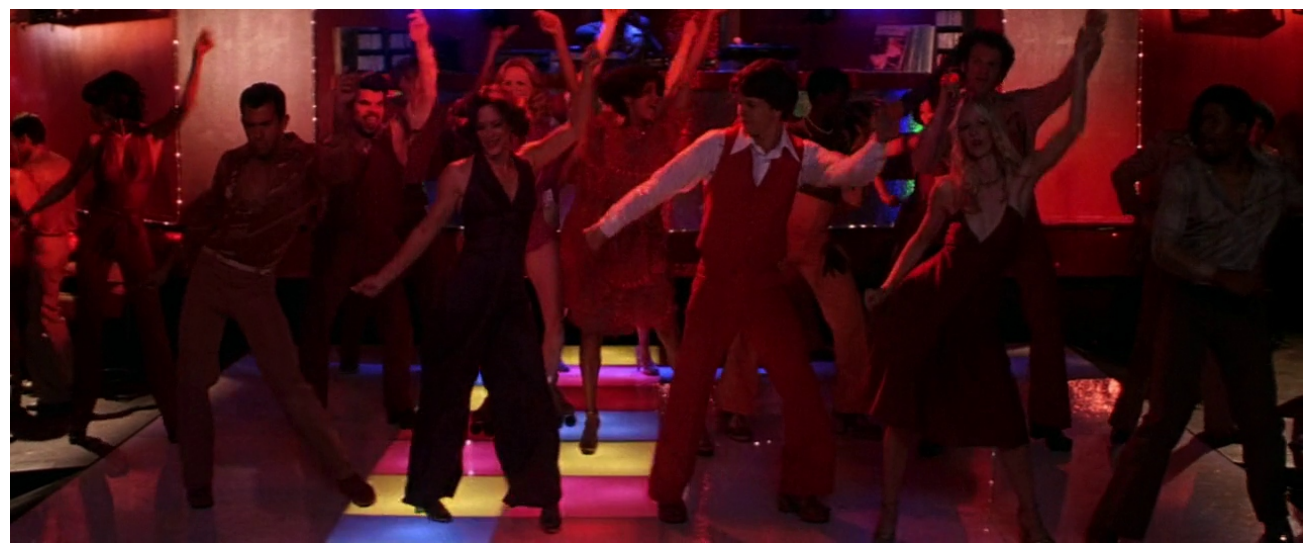

Figura 7 - Exemplo de alusão à cena vermelha de Caminhos perigosos em Boogie nights

$\mathrm{E}$, ao finalizar Boogie nights, o diretor faz uma homenagem clara à última cena de Touro indomável (figuras 8 e 9): os dois protagonistas estão dentro de um camarim, fumando, diante do espelho. Em um dado momento, ambos se levantam e apreciam o reflexo daquilo que os tornou famosos: Dirk Diggler, ator pornô, abaixa as calças para ver seu pênis; Jake LaMotta (Robert De Niro), ex-boxeador, faz movimentos de luta.

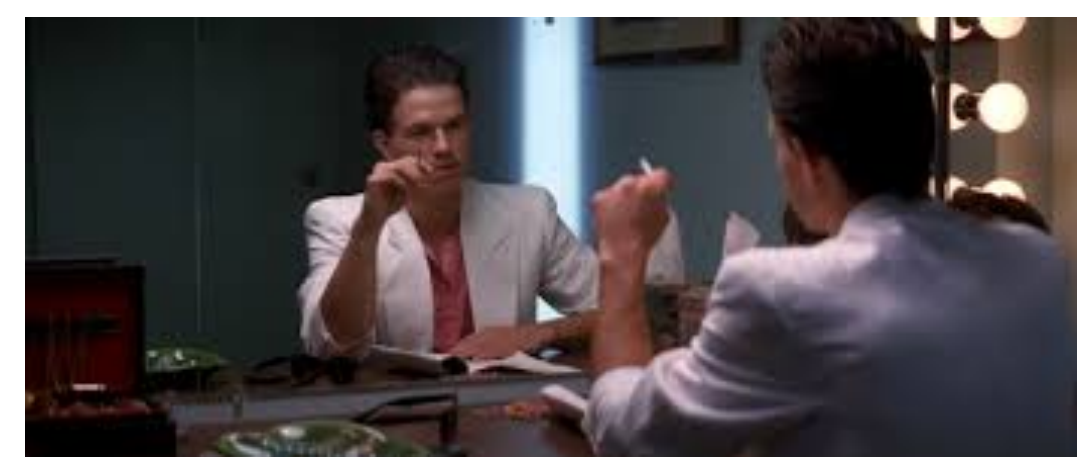

Figura 8 - Cena final de Boogie nights

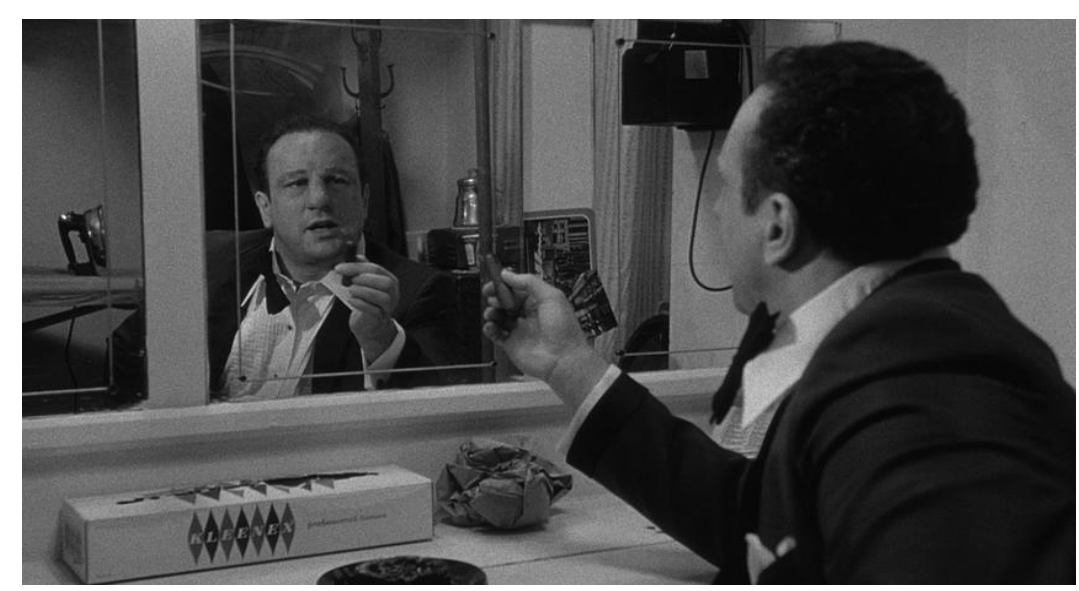

Figura 9 - Cena final de Touro Indomável 
Além dessas similaridades, Scorsese e Anderson também são diretores que encontram na música um terreno fértil para expressar sentimentos em seus filmes. Alguns dos momentos mais significativos na obra dos dois estão atrelados à escolha de uma trilha musical que consegue conversar não apenas com os desdobramentos da cena e as emoções das personagens, mas engaja o espectador de maneira profunda na construção de significados.

Entretanto, todas as citações feitas por Anderson não fazem com que seus filmes sejam cópias dos cineastas que o inspiram. O diretor utiliza essas técnicas e referências para construir uma estética própria. $O$ tratamento diferencial que Anderson dá à construção das personagens, por exemplo, é uma característica muito particular do diretor.

É bem verdade que as possibilidades expressivas da linguagem cinematográfica são inúmeras, mas também não se pode negar a influência que muitos diretores consagrados exercem na produção contemporânea. Da mesma forma como realizadores da atualidade irão impactar as gerações futuras. Por isso, a intertextualidade é praticamente inevitável, seja do cinema com ele mesmo ou com outras formas de arte. No final das contas, o que precisa ser analisada é a marca pessoal que cada diretor imprime em seus trabalhos e, em relação a isso, Anderson tem conseguido manter uma posição de destaque.

Por isso, nos próximos capítulos, as análises fílmicas de Embriagado de amor e Sangue negro contemplam não só os aspectos técnicos das obras, mas também evidenciam características intrínsecas aos filmes de Anderson. Características essas que conferem ao diretor o reconhecimento pela originalidade de seu trabalho. 


\section{CAPÍTULO III}

\section{EMBRIAGADO DE AMOR}

O presente capítulo é composto pela análise fílmica de Embriagado de amor, quarto longa-metragem de ficção da carreira de Paul Thomas Anderson. Os aspectos explorados por esta análise compreendem as características gerais do filme, as interpretações dos simbolismos contidos na narrativa, os traços mais marcantes dos protagonistas, a incomunicação e a relação da trilha musical com o estado emocional das personagens.

\subsection{PUNCH-DRUNK ${ }^{22}$ BARRY}

Lançado em 2002, Embriagado de amor foi roteirizado e dirigido por Paul Thomas Anderson. A obra, que obteve considerável sucesso com a crítica especializada, rendeu ao cineasta o prêmio de Melhor Diretor em Cannes no mesmo ano de seu lançamento. Em linhas gerais, o filme narra a história de Barry Egan (Adam Sandler), um pequeno empresário emocionalmente instável, tímido e solitário, que se apaixona por Lena Leonard (Emily Watson), uma moça independente e bem-sucedida profissionalmente.

Por causa de sua timidez, Barry tem problemas de comunicação, fator acentuado pelas constantes depreciações às quais suas sete irmãs o submetem. Logo após conhecer Lena e recolher da rua um curioso instrumento musical, uma série de acontecimentos inusitados passam a ocorrer na vida do protagonista. Ao perceber que há uma falha no regulamento de uma promoção que dá direito a milhagens aéreas, Barry começa a comprar inúmeros pudins de chocolate, pois os códigos de barras dos produtos podem ser convertidos em milhas. Em certo momento, o escritório dele está repleto de pudins, o que aguça o interesse de várias outras personagens, como sua irmã Elizabeth (Mary Lynn Rajskub) e a própria Lena.

\footnotetext{
${ }^{22}$ A expressão inglesa punch-drunk é derivada do boxe. O termo é utilizado para designar o estado de desorientação de um lutador após levar muitos golpes na cabeça. Tal sensação é descrita como sendo similar àquela que as pessoas experienciam quando estão embriagadas. $\mathrm{O}$ título original de Embriagado de amor é Punch-drunk love, que simboliza tanto a confusão emocional de Barry no início da narrativa, quanto sua "embriaguez" com o sentimento que ele descobre após conhecer Lena.
} 
Além do episódio incomum dos pudins, Barry também se envolve em um caso bizarro de chantagem, desencadeada após ele ligar para uma linha de tele-sexo que tem o objetivo de extorquir seus usuários. Dean (Philip Seymour Hoffman), o dono do esquema telefônico fraudulento, envia seus capangas duas vezes para amedrontar Barry. Na primeira, eles são exitosos e conseguem extrair dinheiro do protagonista; na segunda, os capangas causam um acidente automobilístico que resulta na hospitalização de Lena e na fúria de Barry, que reage à violência e toma as rédeas da situação. O acidente leva Barry a enfrentar Dean pessoalmente, mostrando para o homem que ele já não teme mais suas ameaças.

Em meio a tudo isso estão a relação amorosa que se desenvolve entre Barry e Lena e os conflitos dele com suas irmãs. Intimidado pela presença feminina, Barry demonstra suas inabilidades sociais logo no primeiro encontro com Lena. Na medida em que o relacionamento dos dois progride, Barry se torna mais seguro de si. No entanto, essa progressão não acontece suavemente, já que Barry precisa lidar com as pressões impostas pelas irmãs e a chantagem de Dean.

Muito embora seja categorizado como uma comédia romântica, Embriagado de Amor apresenta elementos temáticos e de linguagem que fogem das convenções narrativas do gênero. Esse afastamento é ressaltado, especialmente, pelos componentes escolhidos por Anderson para narrar o romance e conferir à obra um caráter diferencial.

Um dos principais aspectos pouco convencionais para uma comédia romântica é a composição das personagens principais da trama. Barry é um protagonista solitário, desajustado, com problemas para se comunicar com os outros, principalmente quando se trata de sua própria família. Já Lena aparenta ser uma mulher decidida e experiente, longe da representação clássica da donzela em apuros. A construção das personagens secundárias também é atípica, pois elas possuem características desconcertantes, que complementam a atmosfera caótica criada por Anderson.

Diferentemente dos romances tradicionais, o mocinho, Barry, não possui um amigo próximo, um confidente, ou alguém que lhe dê conselhos; sua relação com a família é turbulenta, as irmãs o reprimem e provocam constantemente, chegando a questionar sua masculinidade por conta do comportamento arredio. Na verdade, a virilidade de Barry e seu papel social como homem são frequentemente postos à 
prova em Embriagado de Amor. Nesse contexto, a postura dominadora de Dean, o antagonista, apresenta-se como o oposto daquela adotada por Barry, que se mostra tímido e esquivo nas relações interpessoais. Essa dicotomia ressalta ainda mais as demonstrações que Anderson dá da vulnerabilidade do protagonista.

Além das personagens incomuns, as escolhas estéticas da fotografia também afastam Embriagado de Amor dos padrões dominantes nas comédias românticas. Com muitas sombras e uma paleta de cores fortemente saturada, a visualidade do filme destoa da fotografia normalmente clara (high key) com tons suaves deste gênero cinematográfico. Anderson utiliza o visual do filme (look) como recurso narrativo na ambientação do universo por ele criado, o que colabora na construção das personalidades e na expressão dos estados emocionais das personagens. As cores também interferem na indicação da função de cada personagem na história, o que varia de acordo com seus arcos de transformação.

No caso de Barry, por exemplo, o azul é o tom mais explorado no seu figurino e nas paredes de seu local de trabalho, já que o rapaz possui traços melancólicos ${ }^{23}$. Por sua vez, as cores dos trajes de Lena tendem a variações de vermelho para demonstrar uma personalidade mais calorosa (figura 10).

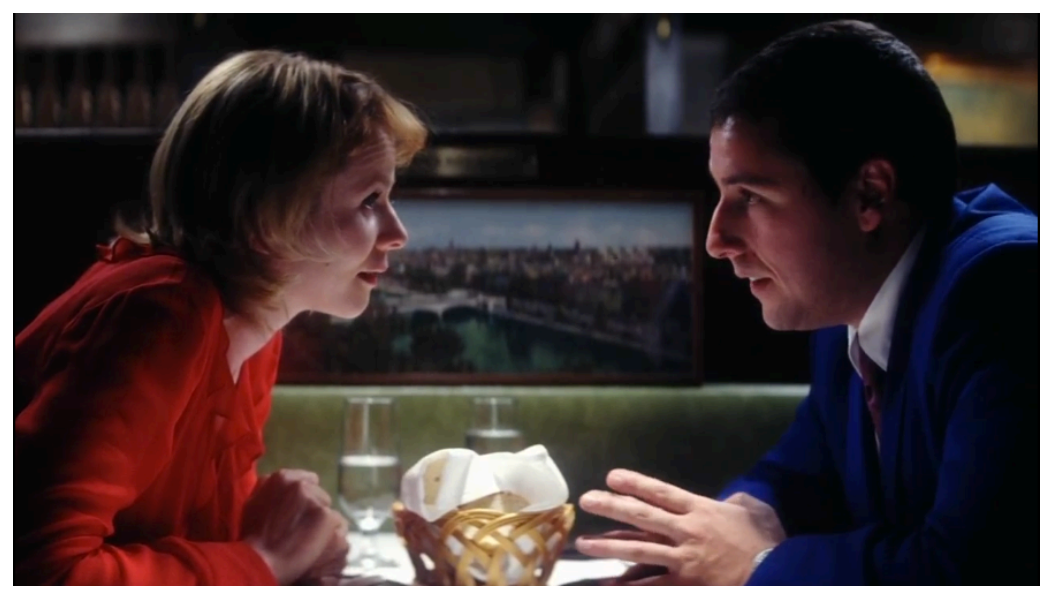

Figura 10 - Lena e Barry no restaurante

Coincidentemente ou não, o azul e o vermelho são cores destacadas em $D e$ olhos bem fechados, última produção de Stanley Kubrick, diretor cujo trabalho detém grande influência na obra de Anderson.

\footnotetext{
${ }^{23}$ No inglês, a palavra blue (azul), além de designar a cor, é utilizada para expressar um estado emocional de tristeza e melancolia.
} 
A presença do vermelho é bem evocativa e não se restringe ao figurino de Lena. No início do filme, Barry presencia um acidente de carro e, logo em seguida, um táxi deixa um harmônio em frente a ele. Os dois carros são vermelhos. Barry não pega o instrumento imediatamente, deixando-o à beira da pista. Só após conhecer Lena, que também usa vermelho na primeira vez em que se encontram, Barry retorna ao local e leva o harmônio para seu escritório.

Em outra cena, quando Barry está no supermercado à procura do produto com o melhor custo-benefício para participar de promoção de milhas aéreas, é possivel ver uma mulher de vermelho ao fundo, andando paralelamente a ele, que vai embora no momento em que o rapaz encontra os pudins (figura 11).

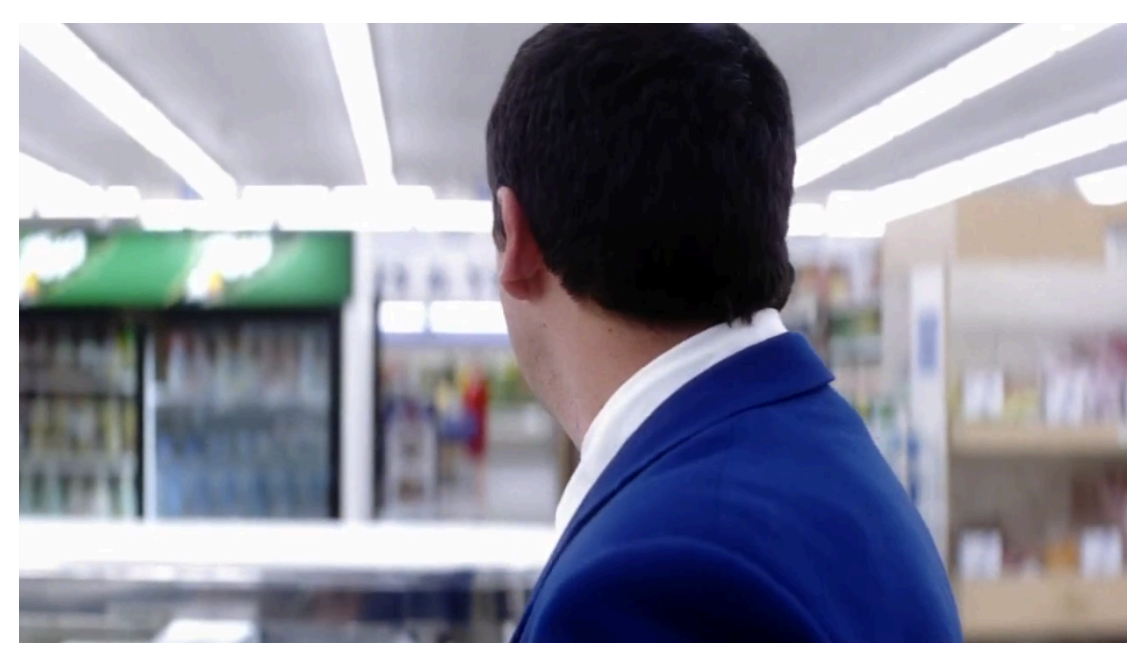

Figura 11 - Barry no supermercado e mulher de vermelho ao fundo

Mesmo com a imagem inteiramente fora de foco, a impressão é que se trata de Lena, e que sua entrada na vida de Barry intensifica gradualmente os conflitos enfrentados por ele. Assim, enquanto o azul reforça os aspectos negativos da personalidade do protagonista, como fragilidade, insegurança e inabilidade social, o vermelho, personificado por Lena, mostra para a personagem as oportunidades que a vida oferece, como amor e felicidade.

Antes de se entregar à paixão por Lena, Barry se sente prisioneiro da própria vida, e todas as suas interações com outras pessoas evidenciam esse estágio de encarceramento constante vivido pela personagem. Em vários momentos do filme, Anderson utiliza os enquadramentos e composição visual para expressar esse aprisionamento de Barry, como pode ser percebido nas figuras 12 e 13. 


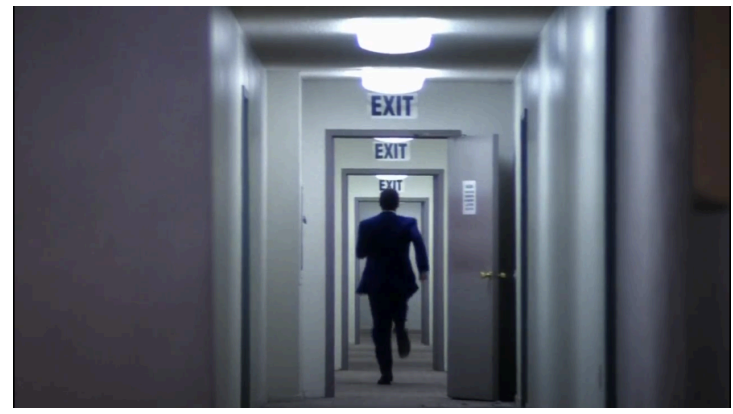

Figura 12 - Corredor do prédio de Lena

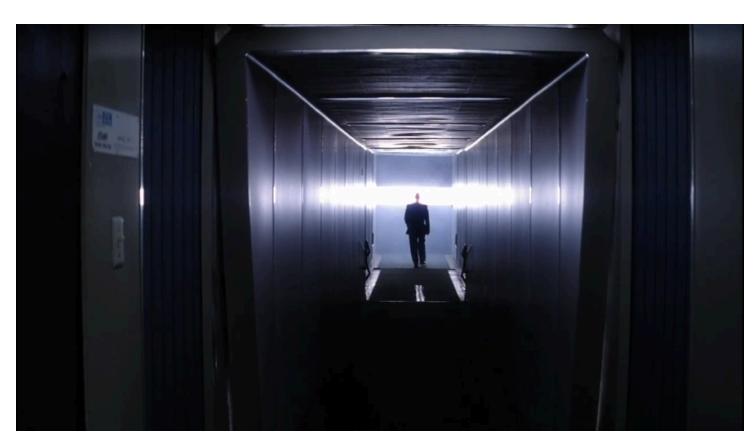

Figura 13 - Corredor de embarque no aeroporto

Barry também se sente oprimido por suas irmãs, que não respeitam sequer seu trabalho. A opressão das numerosas irmãs sofrida por Barry ajuda a entender sua dificuldade em lidar com mulheres. A cena no início do filme, na qual ele se esconde no escritório, imergindo em sombras após o primeiro contato com Lena (figura 14), deixa explícita na tela sua inépcia para relacionamentos com o sexo oposto.

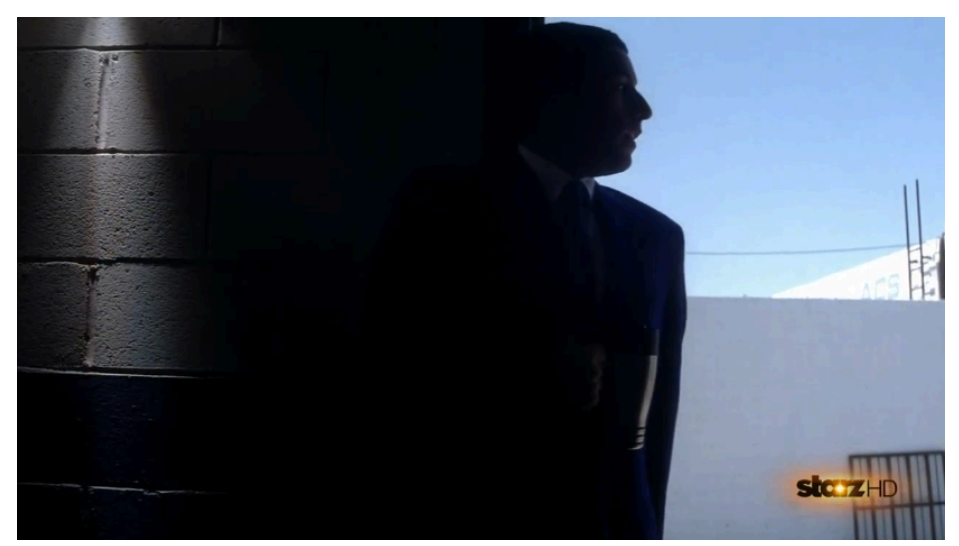

Figura 14 - Barry imerso nas sombras

O mais interessante, no entanto, é que Lena, por mais emocionalmente estável que pareça quando comparada a Barry, mostra indícios de que também tem transtornos comportamentais. A moça confessa a Barry que arquitetou o primeiro encontro entre eles, tendo preparado uma espécie de encontro casual falso para poder conhecê-lo. Como Lena é colega de trabalho de Elizabeth, ela viu uma foto dele que despertou imediatamente o seu interesse em encontrá-lo pessoalmente.

Contudo, à medida que os sentimentos entre os dois desabrocha, Barry vai se libertando de suas amarras, que são essencialmente emocionais. Isso porque ele encontra em Lena alguém que aceita as suas esquisitices, ao invés de censurá-lo, como as irmãs o fazem. À primeira vista, o ápice da relação dos dois é o momento 
em que Barry enfrenta seus demônios e vai atrás de Lena no Havaí. Porém, para as simbologias presentes no filme, a cena que representa a total conexão entre o casal é quando Lena diz a Barry que o instrumento achado por ele trata-se de um harmônio, já que ele, até então, o chamava de "pequeno piano".

Essa revelação tem grande peso simbólico para a narrativa porque o harmônio é a chegada do amor para Barry, pois, assim como Lena, o instrumento apareceu em sua vida de forma inesperada. Da mesma forma como Barry não sabia o nome correto do instrumento, ele também não sabia o que era amor. $E$ foi Lena quem proporcionou a ele o reconhecimento das duas coisas.

O harmônio é uma metáfora para o estado emocional de Barry. Mesmo tentando se mostrar calmo, ele tem um temperamento explosivo, propenso a surtos de violência. Como essa conduta também é motivo de conflito com a sua família, ele se esforça ao máximo para conter sua fúria interna. Após encontrar o instrumento, Barry recorre a ele todas as vezes em que acredita estar prestes a perder o controle e, mesmo sem saber tocá-lo apropriadamente, os sons produzidos pelo harmônio têm o poder de acalmá-lo.

Conforme a trama se desenrola, Barry vai aprendendo a tocar o instrumento e mostra certa desenvoltura ao final. Os sons dissonantes que o harmônio fazia no começo, refletindo a condição emocional conturbada de Barry, dão lugar, ao fim de Embriagado, a uma melodia harmoniosa, pois agora Barry ama, é correspondido e está livre. Faz um certo sentido, então, que quando ele admite esse amor pela primeira vez, sua reação seja carregar o instrumento consigo para ir ao encontro de Lena (figura 15).

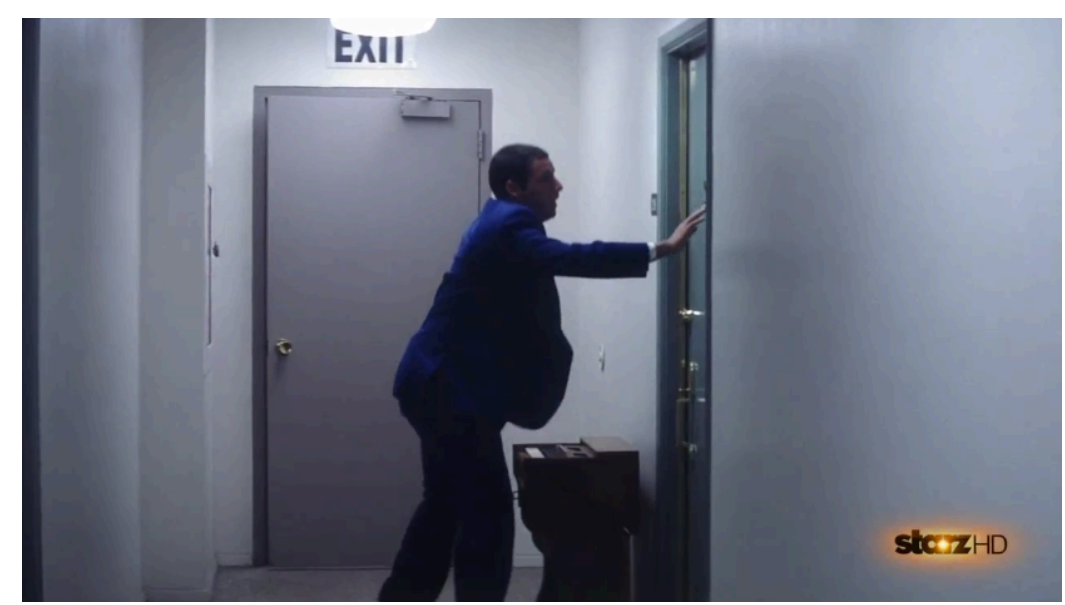

Figura 15 - Barry leva o harmônio até o apartamento de Lena 
Outro elemento simbólico que possui relevância para as temáticas abordadas em Embriagado de amor é o telefone. Diversas vezes durante a narrativa Barry está engajado em conversas telefônicas. A própria apresentação do protagonista na sequência de abertura do filme é feita enquanto ele fala ao telefone. O telefone, analisado de forma mais aprofundada no próximo tópico, tem uma forte ligação com o arco dramático de Barry, bem como com sua solidão e incomunicabilidade.

\subsection{MANIFESTAÇÕES DE INCOMUNICAÇÃO}

Mais que simplesmente contar a história de duas pessoas excêntricas que se conhecem e se apaixonam, Embriagado de amor proporciona uma reflexão sobre as fragilidades humanas, as carências afetivas, sejam elas amorosas ou familiares, e a solidão. O diretor faz uso de vários simbolismos e explora tanto recursos técnicos quanto estéticos para expressar os sentimentos que permeiam a narrativa.

A composição de Adam Sandler para a personagem é muito eficiente, em especial no que refere às inseguranças demonstradas por Barry. A noção de desconforto transmitida pelas expressões de Sandler encontra respaldo na entonação da voz que ele confere à personagem, tal como em suas meias palavras. E é justamente na maneira precária como Barry se expressa verbalmente que se revelam os meandros da incomunicação no filme.

Antes de tudo, é preciso dizer que Barry é uma personagem que mente, seja para as irmãs ou até mesmo para Lena. E, mesmo quando não mente, ele se esquiva da verdade. Barry se serve de pequenas mentiras e omissões para esconder os traços de seu comportamento excêntrico que ele mesmo considera vergonhosos, como os seus acessos de raiva. Porém, mais do que uma forma de proteção, as mentiras contadas por Barry denotam os problemas que ele tem para se comunicar, expor seus sentimentos e conectar-se com os outros, e ele busca desesperadamente essa ligação.

Uma situação recorrentemente escolhida por Anderson para mostrar a ânsia do protagonista em firmar um vínculo afetivo com alguém foi por meio do telefone. Praticamente todos os desdobramentos da trama estão relacionados a ligações telefônicas feitas ou recebidas por Barry: a constatação de que há um erro na 
promoção da companhia aérea, fazendo com que ele adquira centenas de pudins e acumule milhas para viajar gratuitamente pelo resto da sua vida; as inúmeras ligações de suas irmãs, interrompendo-o durante o trabalho e interferindo em sua vida, o que causa ainda mais esgotamento emocional à personagem; quando está prestes a sair do prédio de Lena, após deixá-la em seu apartamento depois do primeiro encontro romântico do casal, o telefone da recepção toca e ele retorna à porta dela e os dois finalmente se beijam; e a ligação que Barry faz para o tele-sexo como forma de aplacar sua carência conversando com alguém que não o conhece e, portanto, não irá julgá-lo.

A ligação para o tele-sexo, a propósito, é um dos exemplos mais marcantes de incomunicabilidade em Embriagado de amor. Sozinho em seu apartamento recortando códigos de barras, Barry encontra um anúncio de sexo por telefone no jornal. A solidão dele o induz a ligar para o serviço, sem pensar duas vezes antes de entregar todos os seus dados pessoais e do cartão de crédito para a atendente. A prudência é menor que a euforia causada pela oportunidade em diminuir um pouco da carência que sente. A mulher na outra linha diz que alguém irá ligar de volta para Barry. Ele concorda e desliga o telefone. A tensão dos segundos que antecedem a ligação da operadora de tele-sexo é enfatizada pelo silêncio. Nesse momento, Anderson sequer faz uso da trilha musical. Quando o telefone toca, Barry não consegue relaxar. Ele anda por todo o apartamento enquanto está ao telefone, e não se mostra interessado nos avanços sexuais feitos pela operadora, que se identifica como Georgia. Barry não está à procura de sexo, tudo o que ele precisa é conversar com alguém.

No dia seguinte, ao sair para trabalhar, o telefone de Barry toca novamente. É Georgia. O anúncio de tele-sexo, na verdade, é um esquema para extorquir dinheiro das pessoas. Quando Barry se nega a pagar, Georgia o ameaça, dizendo que possui todos os seus dados. Daí por diante, Georgia passa a ligar constantemente para ele no trabalho, tentando intimidá-lo. A cada nova ligação, a ansiedade de Barry aumenta, deixando-o transtornado e frustrado, pois o que parecia ser um modo de se comunicar com alguém, acabou se tornando em mais um motivo de vergonha para ele.

Em meio a tudo isso, Anderson continua a desenvolver o relacionamento entre Barry e Lena, e a cena em que ela o visita no trabalho enquanto ele está 
sendo chantageado por Georgia ao telefone transparece a inexperiência de Barry em administrar conflitos que demandam uma dose de sociabilidade. Entretanto, todo o pandemônio causado por Georgia na vida de Barry tem um propósito. Quando o responsável pelo golpe do tele-sexo, Dean, manda seus capangas espancarem Barry, a tentativa resulta em um acidente de carro que coloca Lena no hospital. Nesse momento, Barry não está mais preocupado em conter sua cólera. E, após uma ligação telefônica raivosa para Dean, ele decide ir até o chantagista para enfrentá-lo pessoalmente.

O mais emblemático da situação é o fato de Barry levar o aparelho telefônico junto consigo quando vai confrontar Dean (figura 16).

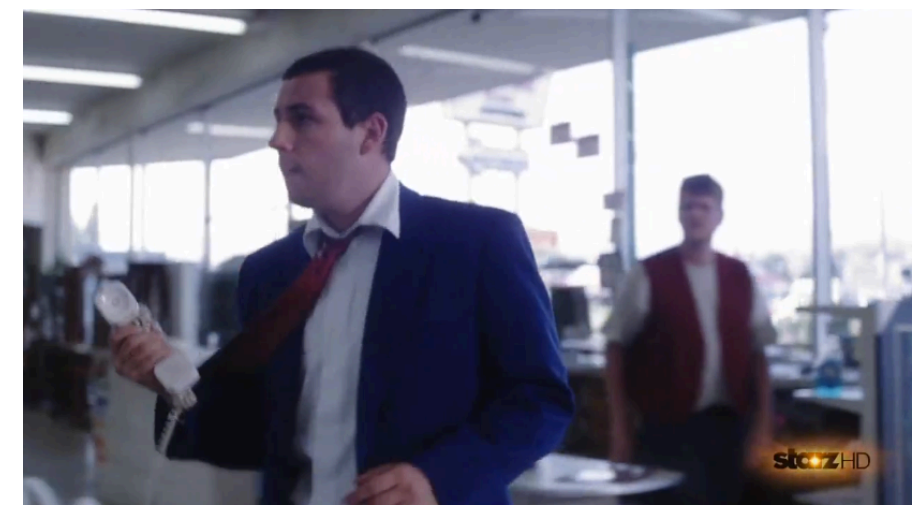

Figura 16 - Barry na loja de Dean com o telefone quebrado

A explicação para o aparelho quebrado que Barry carrega reside no momento em que ele diz a Dean que tem um amor em sua vida e isso the dá forças inimagináveis. Barry não precisa mais buscar as conexões humanas pelas quais tanto ansiava pois agora ele tem Lena.

Antes dessa sequência, porém, há outras cenas que dão indícios de que Barry está em processo de libertação. Quando chega ao Havaí para encontrar Lena, Barry não sabe onde a moça está hospedada. Ao ligar para sua irmã com o intuito de conseguir o endereço, ela o enche de perguntas e o provoca, ao invés de simplesmente dar uma resposta. Então, pela primeira vez, Barry se posiciona contra as intimidações infligidas a ele por suas irmãs. Quando os capangas de Dean batem em seu carro, Barry também os confronta, quebrando os vidros da caminhonete em que os homens se encontram. Essa nova conduta completa seu ciclo quando Barry 
enfrenta Dean mais tarde, provando que a força à qual ele se refere é a de aceitar a si mesmo e reconhecer-se digno de ser amado.

Todavia, a incomunicação em Embriagado de amor não se restringe às limitações que Barry tem para se expressar. Ela também está presente na atitude de suas irmãs. Enquanto Barry não é articulado em sua comunicação, as irmãs falam demasiadamente. Contudo, elas não ouvem, principalmente se é Barry quem está falando. Ao telefone ou pessoalmente, todas as irmãs do rapaz se entregam à verborragia. Isso não constitui o estabelecimento de um vínculo comunicacional entre elas e Barry porque as mulheres ignoram o que o irmão diz, mesmo quando dão a ele a oportunidade de dizer algo.

O tensionamento familiar acompanhado da incomunicação é um traço muito comum na filmografia de Paul Thomas Anderson e, muitas vezes, quem o provoca são as personagens femininas. Coincidentemente ou não, algumas mulheres nos filmes de Anderson possuem a característica de ignorar ou subverter a fala do outro, causando um bloqueio na comunicação. O principal exemplo disso é a mãe de Dirk em Boogie nights que, além de abusar emocionalmente do filho com suas palavras, não dá abertura alguma para que haja possibilidade de um diálogo sensato. No entanto, o diferencial da incomunicabilidade presente em Embriagado de amor são os sons e a trilha musical. $\mathrm{O}$ tópico seguinte é dedicado à análise dessa relação, já que a música do filme, além de contar a jornada emocional de Barry, conversa com o espectador nos momentos em que a personagem adentra os domínios da incomunicação.

\subsection{MÚSICA PARA OS EMBRIAGADOS}

A trilha musical de Embriagado de amor, composta por Jon Brion, talvez seja o momento mais virtuoso do uso da música na filmografia de Paul Thomas Anderson. O diretor, que desde o princípio da carreira sempre demonstrou uma relação muito próxima com a eloquência narrativa proporcionada pela musicalidade, não mede esforços nessa área para engajar o espectador na trama de Embriagado. Sobretudo, a trilha musical do filme atua como forma de explicitar os sentimentos de Barry, principalmente quando ele não é capaz de fazê-lo verbalmente. 
Dessa forma, as composições de Brion oscilam ao longo da narrativa de acordo com o estado emocional do protagonista. Nos momentos em que Barry encontra-se estressado ou prestes a ter uma crise de ansiedade, a música se torna inquietante, carregada de aflição. Nessas ocasiões, ela compete com os diálogos, mostrando o crescente desconforto de Barry e como ele preferia não estar envolvido naquela interação específica. Essas situações estão geralmente associadas à presença de suas irmãs, seja fisicamente ou ao telefone.

Quando está com Lena, no entanto, há uma mudança dramática na função da trilha. A música se torna suave, muito mais harmônica e próxima daquelas utilizadas em comédias românticas tradicionais. Na cena final, quando Lena vai até o galpão onde Barry trabalha e o encontra tocando o harmônio, o rapaz já tem domínio sobre o instrumento e a canção executada por ele está em sintonia com a da trilha musical. $O$ som produzido pelo harmônio e a música que o acompanha são sincrônicos, revelando como Barry encontrou alguma paz de espírito. A harmonia alcançada por Barry, assim como a presença de Lena, dispensam a intervenção verbal, pois a cena traz, provavelmente, a música mais leve de todo o filme, apontando para o espectador que aquela narrativa completou o seu ciclo.

Além de denotar as angústias de Barry e sua gradativa descoberta do amor, ainda existe um terceiro aspecto explorado pela trilha musical: o medo. Algumas cenas antes de os capangas de Dean causarem o acidente de Lena, eles encurralam Barry em um estacionamento e o obrigam a lhes dar dinheiro. Enquanto Barry foge dos capangas, a sequência é embalada por uma música dissonante, confusa, sinalizando o medo que ele está sentindo. Em determinado momento, ele fica preso em um labirinto de vielas, o que aumenta seu desespero e, consequentemente, a urgência da trilha.

A mesma música desarmônica retorna no momento em que Barry discute com Dean ao telefone antes de enfrentá-lo, pois o golpista possui uma personalidade intimidadora. Contudo, nessa cena específica, os três principais sentimentos suscitados pela trilha são trazidos à tona. No começo da conversa telefônica com Dean, a música faz referência ao medo. À medida que Barry sente a raiva pelo homem responsável pela hospitalização de Lena crescer dentro dele, a trilha faz a transição para a música utilizada quando o protagonista se sente desconfortável em situações de interação social. Na mesma sequência, após o 
término da ligação, Barry sai correndo de seu escritório com o aparelho telefônico na mão. Nesse momento, a música é aquela empregada para representar o amor.

Todas essas nuances da trilha conferem uma rica expressividade musical a Embriagado de amor. As múltiplas camadas emocionais presentes no filme são cuidadosamente representadas por meio das músicas, proporcionando uma maior densidade narrativa à obra.

Embriagado de amor é uma produção que apresenta uma abordagem diferenciada para o gênero de comédia romântica. Anderson emprega os recursos sonoros e visuais de maneira criativa para contar a história com sensibilidade e fragilidade, características que se encontram presentes também nas personagens principais. Desta maneira, uma narrativa repleta de sentimentos caóticos ganha vida pulsante nas cores e nas músicas utilizadas pelo diretor. Em comparação a outros filmes de Anderson, como Sangue negro e Magnólia, Embriagado de amor é relativamente esquecido, mesmo tendo concedido ao cineasta o reconhecimento em Cannes. Entretanto, a obra possui vários elementos que fazem transparecer a autoralidade de seu diretor.

No próximo capítulo, que contém a análise de Sangue negro, Anderson apresenta uma narrativa cujo protagonista trilha um caminho oposto àquele seguido por Barry. Enquanto Barry encontra meios para superar as principais dificuldades por ele enfrentadas, com uma trajetória emocional ascendente, o protagonista de Sangue negro afunda-se na solidão e no silêncio. No entanto, mesmo com essa distinção, os dois filmes utilizam o recurso musical para exprimir os sentimentos experimentados por suas personagens principais. 


\section{CAPÍTULO IV}

\section{SANGUE NEGRO}

Este capítulo traz a análise do filme Sangue negro, livremente adaptado do livro Oil! (1927), do escritor estadunidense Upton Sinclair, com roteiro e direção de Paul Thomas Anderson. A análise é formada pelas interpretações acerca das principais temáticas abordadas pelo diretor no filme, com foco em questões como silêncio e solidão. A função narrativa da trilha musical também é investigada com o objetivo de compreender a maneira com a qual Anderson faz uso da música para manifestar as intenções e inquietações das personagens.

\subsection{SANGUE E PETRÓLEO}

Sangue negro é um épico lançado em 2007 que conta a história da ascensão financeira e desumanização de Daniel Plainview, magnata da indústria do petróleo dos Estados Unidos no início do século XX. A história tem início em 1898, quando Plainview ainda é um minerador. Após sofrer um grave acidente, impedindo-o de continuar trabalhando na mina, ele recebe um cheque como compensação pelo seu revés. Sagaz e ambicioso, Plainview investe o dinheiro no ramo petrolífero, tornando-se um prospector bem-sucedido em pouco tempo. Porém, já no primeiro poço prospectado por Plainview, um de seus funcionários morre, fazendo com que ele adote o filho deixado pelo empregado.

Alguns anos depois, Plainview e o filho adotivo, H. W. (Dillon Freasier), viajam para Little Boston, uma pequena cidade da Califórnia, pois Plainview comprou os direitos para extrair petróleo em algumas regiões do estado. Lá, Plainview conhece Paul Sunday (Paul Dano), que alega possuir uma terra com petróleo em abundância. Paul exige uma quantia justa pela localização exata do lugarejo, afirmando que Plainview irá lucrar muito mais após o início das perfurações. Plainview aceita o acordo e segue, juntamente com H. W., para o local indicado por Paul.

Ao chegarem ao condado, Paul não se encontra no rancho de sua família, forçando Plainview a lidar com Eli (Paul Dano), o genioso irmão gêmeo de Paul. Imediatamente, Eli e Plainview travam um relacionamento dissimulado e 
intensamente antagônico. Ambos são gananciosos e calculistas, e demonstram uma avidez implacável para conseguir aquilo que acreditam ser deles por direito. A dinâmica competitiva na qual eles se envolvem é exacerbada pelos seus posicionamentos contrários: Plainview é um homem pragmático e racional; Eli clama que suas ações são movidas pela fé. Nenhum dos dois admite ceder para os valores do outro, e o que aparentemente seria um bom negócio para Plainview acaba se transformando em uma disputa de egos acirrada entre ele e Eli.

No entanto, Plainview convence Eli e sua família de que a extração do petróleo irá trazer prosperidade para a região, iniciando, assim, a drenagem. Não muito tempo depois, há um acidente no poço e $\mathrm{H}$. W. é ferido, resultando na perda de sua audição. O episódio causa o aborrecimento de Plainview, pois ele não se mostra disposto a lidar com a nova condição do filho. Com o intuito de evitar um transtorno maior, Plainview contrata um professor de língua de sinais para acompanhar H. W., acreditando que isso o deixará livre para cuidar de seus negócios.

A trama sofre uma reviravolta quando um homem chamado Henry (Kevin J. O'Connor) aparece e garante ser irmão de Plainview. H. W. não aceita a presença do tio e começa a agir de maneira malcriada. Plainview fica frustrado com a insolência do filho e o manda embora com o professor. No entanto, Plainview descobre que Henry não é seu irmão, mas sim um impostor. Diante da descoberta, ele se enfurece e mata Henry. Sozinho e enraivecido, Plainview ainda é obrigado a aguentar as provocações de Eli.

Depois de conseguir acumular a fortuna que tanto almejou, Plainview não tem ninguém com quem compartilhá-la, já que alienou todos aqueles que, de alguma maneira, demonstraram algum sinal de afeição por ele. Ao final, em um último ato de selvageria, ele acaba com a vida de Eli, sucumbindo definitivamente à escuridão que o envolveu.

Essa ganância de Daniel representa o elemento básico da estrutura social dos Estados Unidos: o modo de vida capitalista. Em Sangue negro, Anderson faz uma crítica aos primórdios daquilo que viria a se tornar uma sociedade pautada pelo consumo e poder financeiro. No entanto, as reflexões sobre o capitalismo estadunidense são apenas o pano de fundo para todas as outras questões abordadas pelo filme. 
Como fez anteriormente em Jogada de Risco, Boogie nights e Magnólia, Anderson traz para Sangue negro a temática do relacionamento familiar centrado na união entre pai e filho. Dessa vez, porém, o diretor confere um caráter muito mais cínico e descrente à relação. É comum nos filmes de Anderson que as personagens procurem outros núcleos familiares para substituir aqueles que são seus de origem. Isso acontece devido à alienação dessas personagens de suas famílias biológicas, já que elas representam a principal causa de tormentos emocionais e psicológicos.

De tal maneira, o conceito de família nos filmes de Anderson não adota sua formação tradicional. Vale ressaltar que o agrupamento dessas personagens desagregadas, sem laços sanguíneos, não se dá apenas por motivos afetivos. Algumas vezes, a motivação da personagem para procurar refúgio fora de seu seio familiar primário é o oportunismo. Nesse aspecto, Sangue negro diferencia-se dos demais filmes do diretor porque o núcleo substituto já se configura como a base do relacionamento, pois $\mathrm{H}$. W. é filho adotivo de Plainview.

Todavia, é possível observar que a atitude de Plainview em adotar o garoto, ainda um bebê à época, não acontece por bondade ou mesmo remorso. As intenções de Plainview são muito menos dignas. Ele percebe que H. W. pode ser um recurso em sua busca por dinheiro e poder, pois a adoção lhe proporciona a oportunidade de vender a imagem de um pai comprometido, que só almeja um futuro melhor para seu filho. Ainda criança, H. W. começa a acompanhar Plainview a suas reuniões de trabalho, nas quais Daniel faz questão de dizer que o menino é seu sócio, reforçando a ideia de se tratar de um negócio familiar, angariando assim a simpatia e confiança dos outros.

É difícil afirmar se o sentimento de Plainview por $\mathrm{H}$. W. chega a ser genuíno ou é apenas mais um de seus artifícios. Daniel sente inveja da relação de H. W. com seu tutor (Robert Hills) e se ressente quando o menino se aproxima de Mary (Sydney McCallister), irmã mais nova de Eli. Porém, a reação de Daniel não condiz com a de um pai com medo de perder o amor do filho, e sim de alguém que não admite ser preterido.

Próximo ao final do filme, o espectador descobre que um $\mathrm{H}$. W. adulto (Russell Harvard) casou-se com a jovem Mary (Colleen Foy) e ainda mantém uma relação próxima com o tutor. Ou seja, H. W. transicionou de seu núcleo substituto forçado, marcado pela adoção de Plainview, para a formação familiar construída por 
ele próprio. Entretanto, não é por coincidência que esse novo agrupamento ao qual H. W. passa a pertencer requer uma figura paterna, simbolizada pelo professor.

Enquanto isso, Plainview já se encontra em completa decadência, entregue ao alcoolismo. É interessante, contudo, como após sua interação final com H. W., depois de tê-lo tratado com desdém e uma agressividade contida, Plainview rememore momentos de afeto com o filho durante sua infância. Essa cena, quando analisada dentro do corpo da obra de Anderson, sugere que Plainview tem alguma esperança de redenção, como acontece com várias personagens nos filmes do diretor. Porém, a sequência seguinte, que marca o encerramento de Sangue negro, assegura ao espectador que Plainview está distante de qualquer salvação que seja.

Ainda no âmbito familiar, uma outra relação presente em Sangue negro que merece destaque é a de Plainview com o seu suposto meio-irmão, Henry, que na verdade é um vigarista que conheceu o irmão legítimo de Plainview. Após a morte do verdadeiro irmão, ele decide assumir sua identidade e se aproveitar da prosperidade de Plainview. Mais uma vez, a formação de um núcleo familiar é marcada pelo oportunismo. Henry convence Plainview de que é, de fato, seu irmão e, por um breve momento, Plainview vislumbra uma conexão humana que não seja calcada nas vantagens financeiras.

Como muitas outras personagens na filmografia de Anderson, Plainview está envolto em sua própria solidão. O aparecimento de Henry faz com que o protagonista experiencie não se sentir mais tão solitário. Porém, conflitos surgem quando $\mathrm{H}$. W. não rejeita o tio e desconfia de seus verdadeiros propósitos. O menino chega a atear fogo nas coisas de Henry, o que leva Plainview a mandar o filho embora, juntamente com o tutor, do acampamento onde moram.

Ao finalmente descobrir que Henry é um impostor, a fúria de Plainview extrapola todo e qualquer sentimento de fraternidade que o farsante possa ter despertado nele. Nem seu retorno à completa solidão parece importar mais. Plainview não hesita em matar Henry a sangue frio, enterrando-o em uma cova rasa cheia de petróleo (figura 17), uma trágica lembrança daquilo que realmente importa em sua vida. 


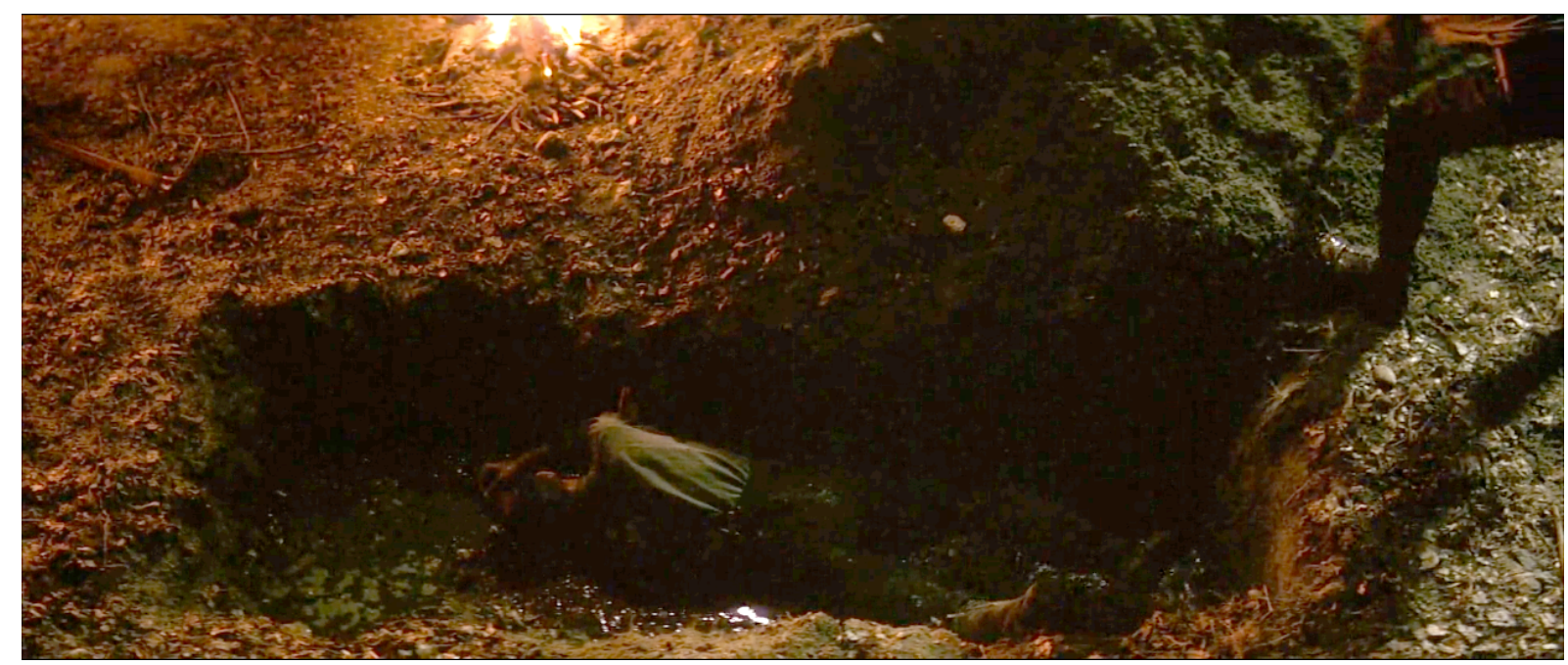

Figura 17 - Corpo de Henry na cova com petróleo

Após a frustração sofrida, a exasperação de Plainview só é proporcional ao seu orgulho. E por ter se deixado enganar por Henry, seu orgulho ferido faz com que ele desconfie ainda mais das pessoas. É inadmissível para o protagonista conviver com quem considera incompetente e inferior. O problema é que Plainview julga todos aqueles que o cercam como sendo incompetentes e inferiores. Esse desprezo eleva ainda mais seu nível de isolamento emocional, disfarçado por ele por meio da soberba.

Plainview acredita estar acima de qualquer contestação ou julgamento, sendo esse um dos motivos que o leva a entrar em confronto com Eli. O rapaz, que também é impulsionado pela ambição e pelo orgulho, enxerga nas pessoas oportunidades, da mesma maneira que Plainview. Ao deparar-se com uma personalidade disposta a contrariá-lo em suas próprias verdades, a fachada de equilíbrio de Plainview é constantemente posta à prova, e o resultado desses testes é devastador para sua humanidade.

Nesse contexto, a fé também desempenha um papel crucial para a narrativa de Sangue negro, já que tanto Eli quanto Plainview sofrem de um complexo de superioridade quase divino. Essa característica é muito mais vistosa em Eli pelo fato de ele fundar um culto cristão, denominado de Igreja da Terceira Revelação. Entretanto, a fé de Plainview em si próprio não o distancia do fanatismo religioso de Eli. Com sua oratória, Eli consegue arregimentar os trabalhadores pobres da região para sua seita, formando uma espécie de rebanho. Os seguidores de Eli parecem 
acreditar piamente naquilo que ele prega, o que enfurece Plainview e confirma as suas suspeitas de que ele próprio é um deus entre idiotas.

Contudo, a religião é apenas um artifício que Eli encontra para concretizar aquele que ele acredita ser o seu propósito na vida: tornar-se um grande líder. A vaidade de Eli exige que suas palavras sejam ouvidas e tomadas como verdades absolutas. Não muito diferente do sentimento de Plainview em relação a si mesmo. $\mathrm{Na}$ cena final, Plainview grita que ele é a terceira revelação, o escolhido pelo Senhor, negando a posição de Eli como líder espiritual. De certa forma, tanto Daniel quanto Eli são falsos profetas: sendo que um oferece prosperidade e o outro salvação. No fim das contas, apenas eles mesmos se beneficiam da crença alheia nas promessas vazias que proferem.

Outro aspecto relevante que merece ser comentado é a relação entre o título e as palavras finais de Plainview. No original, em inglês, Sangue negro é There will be blood, traduzido livremente para o português por algo como "haverá sangue". O último encontro entre Eli e Plainview termina em tragédia. Plainview, bêbado, esmaga o crânio de Eli com um pino de boliche, matando o rapaz e sentando-se em seguida próximo à poça de sangue. O título do filme é o compromisso de Anderson com a violência física e emocional da narrativa, confirmada pela fala de Plainview após o assassinato: "I'm finished" (figura 18).

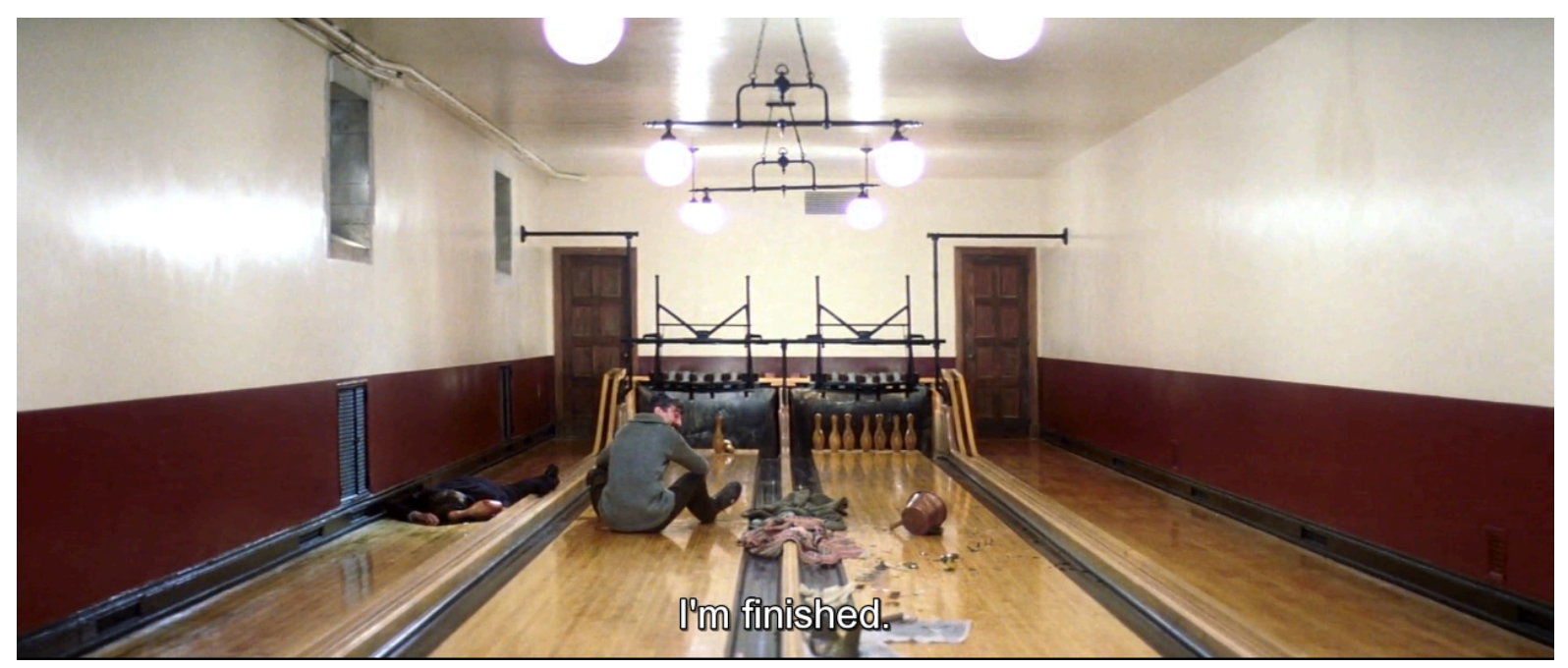

Figura 18 - Última cena de Sangue negro 
A expressão em inglês l'm finished pode significar que alguém terminou de executar uma tarefa ou que a pessoa está literalmente "acabada". No caso de Plainview, exprime os dois sentidos, além de suscitar um terceiro: o cumprimento da promessa de que haveria sangue. Essa cena tem relação direta com aquela em que Plainview mata Henry. Menos brutal que a morte de Eli, a cena da morte de Henry não mostra seu sangue. No entanto, Plainview o joga na cova com petróleo, o sangue negro da obra.

\subsection{O SILÊNCIO DE PLAINVIEW}

$\mathrm{Na}$ mesma intensidade com a qual solidão e incomunicação atuam em Embriagado de amor, solidão e silêncio operam em Sangue negro. Um dos primeiros indicativos de que a narrativa do filme é pautada pelo sentimento de solidão está nas suas paisagens. $\mathrm{O}$ ambiente árido, desértico, complementa a personalidade de Plainview, informando ao espectador que, assim como o local no qual se encontra, a única coisa que parece correr pelas suas veias é petróleo.

A ligação que Plainview possui com a terra é superior àquela que ele tem com as pessoas, até porque, é do chão que ele extrai os meios para seu sucesso. Com um discurso eloquente e charmoso, Plainview é capaz de convencer todos aqueles que encontra a darem-no o direito de explorar o petróleo em seus terrenos. $O$ que as pessoas não percebem é a dissimulação nas suas palavras, já que Plainview as enxerga como mercadorias, lucro, e não seres humanos.

Devido a isso, praticamente toda a comunicação de Plainview com aqueles que o cercam é uma farsa. Ele odeia as pessoas, mas ama o que elas têm a oferecer. Para alcançar seu objetivo, precisa ocultar sua aversão a tudo aquilo que não reflete ele próprio. No entanto, em sua essência, Plainview prefere o silêncio. Seu comportamento protocolar é taciturno e observador. Se ele precisou construir uma persona que o tornasse aparentemente receptivo, foi apenas para não perder de vista suas metas. As demonstrações mais claras da conduta circunspecta de Plainview ficam evidentes nas longas caminhadas que ele faz, primeiramente ao lado de H. W. e, depois, de Henry.

Ao incorporar sua persona em público, Plainview se coloca como homem de negócios inteligente e obstinado. Porém, é nos momentos de silêncio que sua 
verdadeira natureza se revela. Na cena em que dois empresários tentam comprar os poços prospectados por Plainview em Little Boston, os homens dizem que a transação irá torná-lo um milionário. Como negociante que é, Plainview, de forma polida, tenta tirar o máximo proveito da operação. Porém, após os negociantes sugerirem que ao aceitar o acordo ele terá mais tempo para cuidar do filho, o semblante de Plainview muda drasticamente e ele se cala (figura 19).

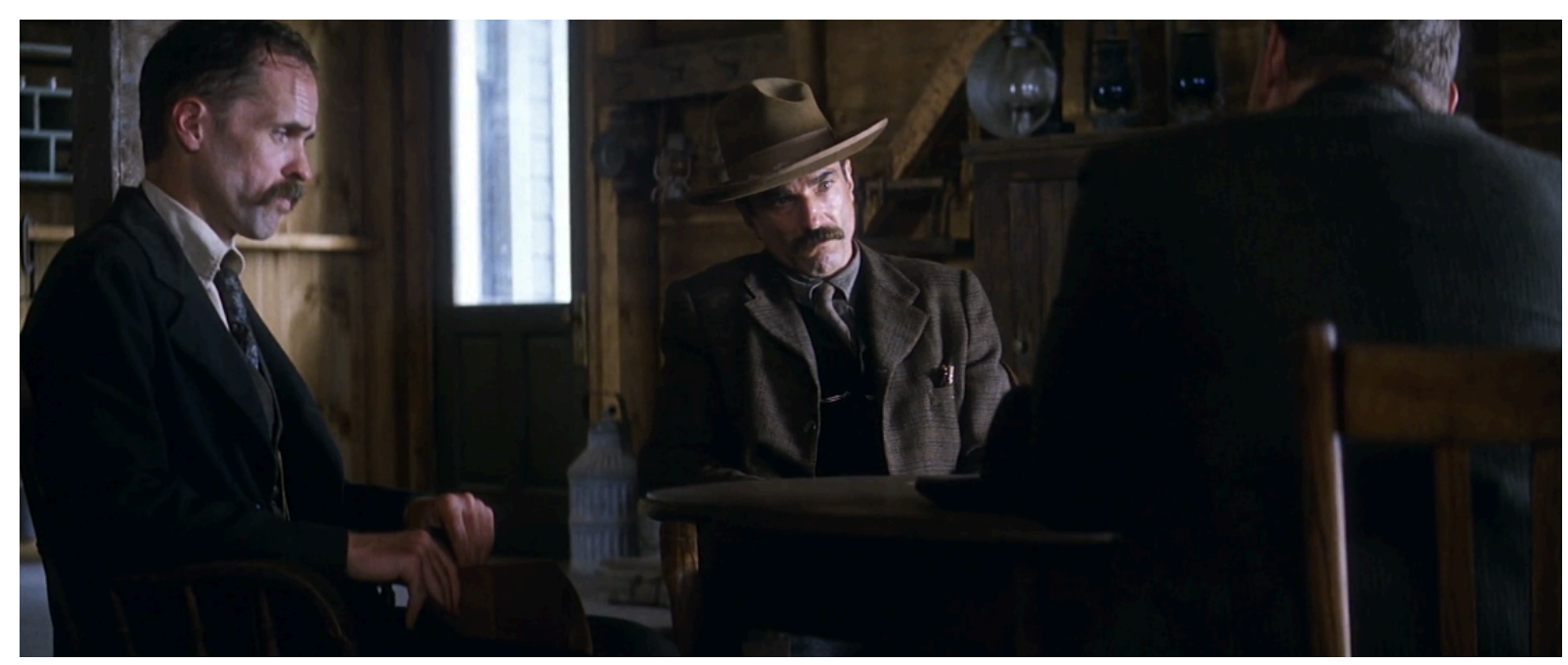

Figura 19 - Desaprovação de Daniel ao comentário dos empresários

Fica claro que, para Plainview, é inconcebível que alguém tenha a ousadia de ensiná-lo como cuidar da própria vida. O silenciamento de Plainview exprime a raiva crescente dentro dele. Quando ele finalmente fala, suas palavras saem violentas, em forma de ameaça.

Um outro momento revelador do silenciamento de Plainview é quando ele finalmente percebe que Henry é um impostor. Os dois estão conversando sozinhos na praia e Plainview faz referência a um evento que, caso Henry fosse seu verdadeiro irmão, teria reconhecido. Como Henry reage com indiferença, Plainview se mostra imediatamente suspeito. Suas expressões indicam seus sentimentos sem que ele precise falar, até porque, a constatação de que estava sendo enganado todo o tempo o deixa mudo.

Seu rosto transmite a confusão inicial de não entender a reação de Henry (figura 20), que rapidamente se transforma em incredulidade (figura 21), dando lugar ao reconhecimento da farsa, à frustração (figura 22) e, por fim, à raiva (23). 


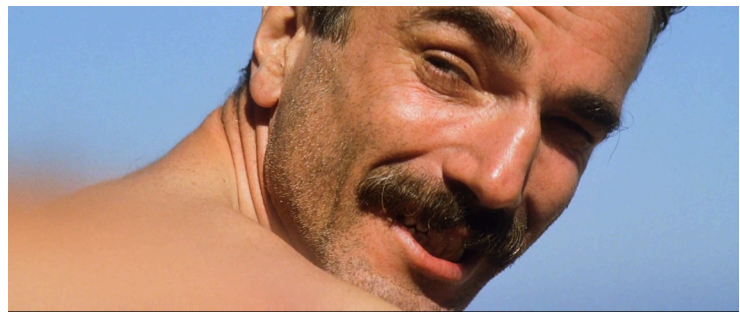

Figura 20 - Daniel confuso com a indiferença de Henry

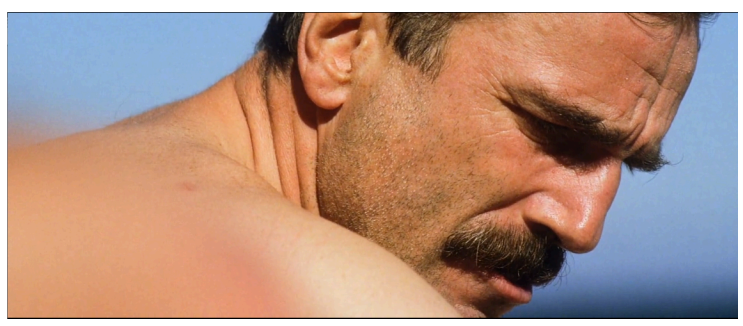

Figura 22 - Daniel chega à conclusão que está sendo enganado

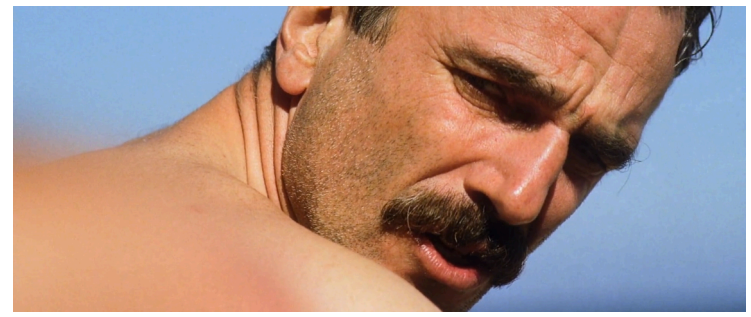

Figura 21 - Incredulidade de Daniel perante a possibilidade de Henry ser um impostor

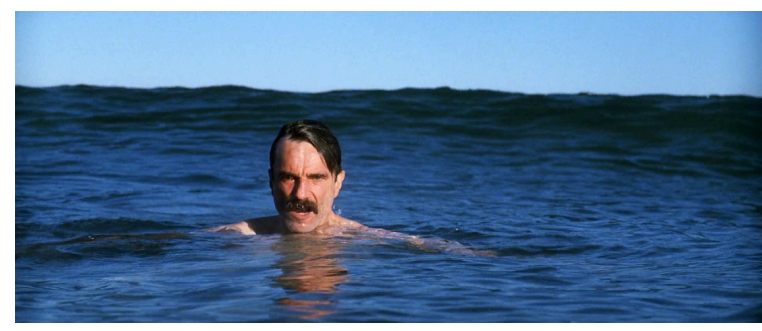

Figura 23 - Daniel se entrega à raiva

Enquanto todas essas emoções transpõem a fisionomia de Plainview, ele ensaia a articulação de algum discurso, mas logo desiste. Palavras seriam insuficientes para manifestar as sensações que o dominam.

$\mathrm{Na}$ cena seguinte, quando Henry e Plainview estão no que parece ser um cabaré, Henry se aproxima de Plainview e pede a ele um pouco de dinheiro. Ele permanece em silêncio. Henry insiste. Plainview não consegue sequer olhá-lo nos olhos. Sentado em um canto, no escuro, é quase impossível ver todo o rosto de Plainview durante a sequência. Ainda sem falar nada, ele dá o dinheiro a Henry por conta de sua insistência, fazendo com o que outro se afaste. Lentamente, a figura de Plainview vai mergulhando cada vez mais nas sombras, até a tela escurecer totalmente. A imersão nessa escuridão significa o retorno de Plainview ao seu estado de isolamento, à solidão, ao silêncio.

A representatividade do peso atribuído ao silêncio verbal em Sangue negro também fica evidente quando $\mathrm{H}$. W. perde a audição por conta de um acidente no poço de petróleo. Após o ocorrido, o garoto necessita de um professor para ensinálo a língua de sinais e mediar sua comunicação. A partir daí, a relação com Plainview começa a se deteriorar. Embora H. W. não perca a habilidade total da fala, ele escolhe calar, já que não faz sentido expressar-se verbalmente sem poder ouvir o som da própria voz. Com isso, o silêncio de H. W. resulta no recrudescimento do 
silêncio de Plainview para com o restante do mundo. Ironicamente, o silenciamento verbal de $\mathrm{H}$. W. é o que lhe dá a oportunidade de forjar as relações que, futuramente, irão constituir sua nova família, composta por Mary e o professor.

A barreira erguida entre pai e filho adotivo conduz as ações finais das duas personagens na narrativa: já adulto, e por meio do professor, H. W. informa a Plainview que quer sua parte na sociedade para fundar a própria empresa. A rejeição é a única resposta de Plainview, que na tentativa de humilhar o filho conta a ele que não é seu pai legítimo.

Os delírios de grandiosidade de Plainview, de passar seu legado adiante e perpetuar suas conquistas, simplesmente desmoronam com o afastamento do filho. A ideia do negócio familiar vendida por Plainview não mais se sustenta, talvez porque desde $\mathrm{o}$ início ela tenha sido edificada sobre falsos pretextos. A trajetória dessas duas personagens é desenhada para culminar em ruptura, que teve como principal catalizador o silenciamento verbal.

Além desses episódios comentados acima, Sangue negro apresenta outras sequências que não possuem diálogos, seja com o intuito de exprimir a tensão entre as personagens ou para privilegiar o desenvolvimento da trama por meio da composição visual e, também, da sonora. O silêncio verbal tem um grande impacto na narrativa de Sangue negro, sendo a trilha musical um dos fatores que contribui para essa percepção. No tópico seguinte, explora-se como a combinação entre silêncio e música pode expandir a compreensão do espectador sobre as emoções e os significados existentes no filme.

\subsection{A ORQUESTRA DO DESERTO}

Como já estabelecido pelo referencial teórico que fundamenta esta pesquisa, a música na produção audiovisual tem o poder de provocar diversos sentimentos na audiência, complementando a mensagem visual da obra. Ademais, a trilha musical tem a função de acrescentar camadas à narrativa, tornando-a mais complexa. As relações entre imagem e música geram material expressivo fértil no processo de produção de sentidos nos filmes.

A partir disso, a análise da trilha sonora de Sangue negro revela que a música desenvolve um importante papel no entendimento dos propósitos narrativos de Paul 
Thomas Anderson. Esse elemento auditivo transmite e reforça alguns dos principais aspectos temáticos presentes no filme, tais como cobiça, vingança e perdição. Composta pelo músico britânico Jonny Greenwood, a trilha incorpora toda a dramaticidade da história, em que a urgência das músicas dá o tom à atmosfera de apreensão confeccionada por Anderson.

Assim como o filme contém alguns períodos consideráveis sem diálogos, a trilha musical também apresenta momentos extensos de ausência. A música só é introduzida aos 7 minutos após o início do filme e, mesmo assim, sem ser de forma contínua. Apenas depois do primeiro discurso verbal, quase aos 15 minutos, é que a música de Sangue negro assume uma presença vigorosa na obra.

A trilha relembra constantemente a violência emocional e a solidão das personagens no filme em questão. Os acordes são tão desconcertantes quanto a personalidade de Plainview e, em vários momentos, o volume se torna muito alto e as notas musicais dissonantes. Quando Plainview faz seus discursos, embora ele mantenha sua fachada de civilidade, a trilha insinua o fingimento contido em suas palavras. Nesses momentos, a música aproxima-se do crescente medo suscitado pelas trilhas dos filmes de terror, denunciando ao espectador as verdadeiras intenções do protagonista.

Um aspecto que também se sobressai na trilha musical de Sange negro é a designação de funções para os diferentes instrumentos, especialmente os de cordas e a percussão. Enquanto a entrada de músicas dominadas pelos instrumentos de cordas ressalta a faceta catastrófica da trama, o som das percussões segue um motivo tribal, evidenciando a primitividade dos cenários e dos impulsos de suas personagens, sobretudo de Plainview.

A música em Sangue negro indica, com efeito, o declínio iminente de Plainview. Sempre sombria e angustiante, a trilha capta o furor com o qual as personagens se afundam em seus próprios vícios e obsessões. Em consonância com os silêncios verbais recorrentes no filme, as pausas musicais acentuam a vastidão e esterilidade das paisagens, bem como a solidão impregnada nelas. Não parece haver pessoas felizes em Sangue negro, e a trilha se assegura em esclarecer isso para a audiência. E, em uma última crítica sarcástica à miserabilidade das personagens, o único momento em que a trilha manifesta algum 
sinal de regozijo e satisfação é quando Daniel cumpre sua promessa e faz Eli sangrar.

Em sua crítica à sociedade estadunidense, Sangue negro questiona se os caminhos do capitalismo - representado por Plainview - e do fanatismo religioso presente na figura de Eli - são responsáveis pelas percepções que regem o que é denominado como bem e mal. Para além disso, Anderson também indaga sobre as consequências das ações motivadas apenas por cobiça e poder. Nesse contexto, o caminho escolhido por Plainview privilegiou seus ganhos financeiros em detrimento das suas ligações afetivas.

Já o silêncio e a solidão do protagonista refletem seu sentimento de autossuficência, além de indicarem o desprezo para com os laços emocionais que poderia ter constituído com o filho adotivo ou o suposto irmão. A brutalidade com a qual Plainview interrompe suas relações interpessoais também é manifestada na impetuosidade da trilha musical, que sempre relembra o fato de Sangue negro ser uma narrativa sobre violência e hostilidade. E diante da mesma aspereza com a qual é apresentado ao espectador, nas sombras e solitário, Plainview conclui sua jornada. 


\section{CONSIDERAÇÕES FINAIS}

Quando se pensa em silêncio verbal e incomunicabilidade, é comum que estes elementos sejam relacionados à falta de comunicação ou à inexistência de sentidos. No entanto, com a averiguação feita nesse estudo, foi possível constatar como tanto o silenciamento quanto a incomunicação têm seus próprios meios de gerar significados e, por conseguinte, comunicar de outras maneiras. Ao serem articulados como artifícios narrativos, silêncio verbal e incomunicação expandem as possibilidades expressivas do audiovisual.

No caso de Embriagado de amor e Sangue negro, o silêncio verbal e a incomunicação das personagens principais, Barry e Plainview, respectivamente, estão diretamente atrelados a um estado de isolamento emocional. Calar ou incomunicar para as personagens de Paul Thomas Anderson nos filmes analisados vai muito além dos imperativos da fala: são ações que refletem uma condição profunda de solidão. Assim, o diretor faz uso dos elementos para produzir significados em suas narrativas e, também, compor as camadas de complexidade das personagens.

Ao inserir a música como um mecanismo integrante desses universos verbalmente silenciosos e incomunicativos, Anderson reforça para o espectador as carências emocionais de suas personagens e, sobretudo, seus anseios. A trilha de Jon Brion em Embriagado de amor acompanha a evolução dramática de Barry Egan, estabelecendo continuamente para a audiência as mudanças sofridas pelo rapaz ao longo do filme: do instante inicial de confusão e o evidente problema em se comunicar, passando pela descoberta de um novo sentimento para sua vida até o enfrentamento de seus medos.

Por sua vez, as músicas compostas por Jonny Greenwood para Sangue negro seguem o caminho inverso das de Embriagado, mas com a mesma efetividade narrativa. Se Barry é uma personagem que evolui emocionalmente, Plainview apresenta-se como o seu oposto, visto que a trajetória por ele percorrida leva a um abismo emocional superior àquele apresentado no início da história. Dessa forma, a trilha de Sangue marca a involução de Plainview como ser humano, 
recorrendo constantemente a elementos sonoros que dão mais ênfase a sua decadência.

Nos dois casos, as trilhas musicais têm características muito próprias para cada momento das narrativas, estando em consonância com as tramas tecidas por Anderson, os aspectos mentais e comportamentais atribuídos às personagens, e as composições visuais empregadas pelo diretor. Portanto, não seria um equívoco concluir que, tanto em Embriagado de amor quanto em Sangue negro, música e imagem constituem uma poderosa relação, operando conjuntamente e de forma harmônica em prol das histórias contadas por Anderson.

Apesar das conclusões alcançadas pela pesquisa, é importante destacar que a análise de uma produção audiovisual, mesmo quando direcionada por uma temática específica, não significa o esgotamento das possibilidades interpretativas da obra. O exercício da análise, na verdade, cria a abertura para outras perspectivas, permitindo o desdobramento do tema inicial em futuros objetos de pesquisa. Nesse contexto, a experiência proporcionada por este trabalho motivou o interesse na investigação de outros aspectos dos filmes de Anderson, como a deterioração das relações familiares tradicionais na contemporaneidade.

Esta monografia, muito embora marque o encerramento de um ciclo, inaugura para a autora uma série de alternativas possíveis dentro do campo da análise fílmica e da pesquisa acadêmica. $E$, da mesma maneira como o silêncio verbal e a incomunicação ocasionam diversas interpretações prováveis, este trabalho é apenas uma das inúmeras perspectivas possíveis na compreensão da obra de Paul Thomas Anderson. 


\section{BIBLIOGRAFIA}

ANDERSON, Paul Thomas. Introduction. In: THOMPSON, David (Ed.). Altman on Altman. Londres, Reino Unido: Faber \& Faber, 2006.

AUMONT, Jacques. A estética do filme. Campinas: Papirus, 2012. ; MARIE, Michel. Dicionário teórico e crítico de cinema. Campinas: Papirus, 2012.

BAITELLO Jr, Norval, (Org.). Os meios da incomunicação. São Paulo: Annablume, CISC, 2005.

BISKIND, Peter. Como a geração sexo-drogas-e-rock'n'roll salvou Hollywood. Rio de Janeiro: Intrínseca, 2009.

BORDWELL, David; THOMPSON, Kristin. Film art: an introduction. Nova York, Estados Unidos: McGraw-Hill, 2001.

BROWN, Blain. Cinematography: theory and practice - Image making for cinematographers and directors. Oxford, Reino Unido: Focal Press, 2012.

CHION, Michel. Audio-vision: sound on screen. Nova York, Estados Unidos: Columbia University Press, 1994.

COHEN, Annabel J. The functions of music in multimedia: a cognitive approach. Seul, Coreia do Sul: Seoul National University, 1998.

COSTA, Fávia Cesarino. Primeiro cinema. In: MASCARELLO, Fernando (Org.). História do cinema mundial. Campinas: Papirus, 2012. P. 17-52.

DUNCAN, Paul. Stanley Kubrick - Filmografia completa. Colônia, Alemanha: TASCHEN, 2013.

ENCABO, Enrique. Reinventing sound: music and audiovisual culture. Newcastle, Reino Unido: Cambridge Scholars Publishing, 2015.

FORAIN, Felipe. A procura do silêncio. Rio de Janeiro: Tempo Brasileiro, 2013. 
GAUDREAULT, André; JOST, François. A narrativa cinematográfica. Brasília: Editora Universidade de Brasília, 2009.

GIUNTINI, Mauro. A narrativa cinematográfica de Alejandro González Iñárritu. (Tese) Doutorado. Programa de Pós-Graduação em Comunicação, Universidade de Brasília, 2015.

KOVADLOFF, Santiago. O silêncio primordial. Rio de Janeiro: José Olympio, 2003. MANZANO, Luiz Adelmo F. Som-imagem no cinema: a experiência alemã de Fritz Lang. São Paulo: Perspectiva, 2014.

MASCARELLO, Fernando (Org.). História do cinema mundial. Campinas: Papirus, 2012.

MCKEE, Robert. Diolague: the art of verbal action for the page, stage, and screen. Nova York, Estados Unidos: Hachette Book Group, 2016.

ORLANDI, Eni Puccinelli. As formas do silêncio: no movimento dos sentidos. Campinas: Editora da Unicamp, 2011.

SEGER, Linda. Creating unforgattable characters: a practical guide to character development in films, TV series, advertisements, novels \& shot stories. Nova York, Estados Unidos: Holt Paperbacks, 1990.

SONTAG, Susan. A vontade radical. São Paulo: Companhia das Letras, 2015.

SPERB, Jason. Blossoms and blood: postmodern media culture and the films of Paul Thomas Anderson. Austin, Estados Unidos: University of Texas Press, 2013.

STAM, Robert. Introdução à teoria do cinema. Campinas: Papirus, 2013.

VANOYE, Francis; GOLIOT-LÉTÉ, Anne. Ensaio sobre a análise fílmica. Campinas: Papirus, 2012. 


\section{FILMOGRAFIA}

2001: UMA Odisseia no Espaço. Direção de Stanley Kubrick. Estados Unidos e Reino Unido: Stanley Kubrick Productions, 1968. 142 minutos.

A AVENTURA. Direção de Michelangelo Antonioni. Itália: Cino Del Duca, 1960. 143 minutos.

A NOITE. Direção de Michelangelo Antonioni. Itália: Nepi Film, 1961. 122 minutos.

A ÚLTIMA Tentação de Cristo. Direção de Martin Scorsese. Estados Unidos: Cineplex Odeon Films, 1988. 163 minutos.

ATRAVÉS de um Espelho. Direção de Ingmar Bergman. Suécia: Svensk Filmindustri, 1961.91 minutos.

BARRY Lyndon. Direção de Stanley Kubrick. Estados Unidos e Reino Unido: Hawk Films, 1975. 187 minutos.

BOOGIE Nights - Prazer sem Limites. Direção de Paul Thomas Anderson. Estados Unidos: Ghoulardi Film Company, 1997. 155 minutos.

CÃES de Aluguel. Direção de Quentin Tarantino. Estados Unidos: Live American Inc., 1992. 99 minutos.

CAMINHOS Perigosos. Direção de Martin Scorsese. Estados Unidos: Taplin-PerryScorsese Productions, 1973. 112 minutos.

CARRUAGENS de Fogo. Direção de Hugh Hudson. Reino Unido: Allied Stars Ltd, 1981. 124 minutos.

DE OLHOS Bem Fechados. Direção de Stanley Kubrick. Estados Unidos e Reino Unido: Pole Star, 1999. 159 minutos.

O DESERTO Vermelho. Direção de Michelangelo Antonioni. Itália e França: Film Duemila, 1964. 120 minutos. 
DUNKIRK. Direção de Christopher Nolan. Estados Unidos, Reino Unido, França e Holanda: Syncopy Inc., 2017. 106 minutos.

ELA. Direção de Spike Jonze. Estados Unidos: Annapurna Pictures, 2013. 126 minutos.

EMBRIAGADO de Amor. Direção de Paul Thomas Anderson. Estados Unidos: New Line Cinema, 2002. 95 minutos.

JOGADA de Risco. Direção de Paul Thomas Anderson. Estados Unidos: Rysher Entertainment, 1996. 102 minutos.

LUZ de Inverno. Direção de Ingmar Bergman. Suécia: Svenk Filmindustri, 1963. 81 minutos.

MAGNÓLIA. Direção de Paul Thomas Anderson. Estados Unidos: Ghoulardi Film Company, 1999. 188 minutos.

MEDIANERAS: Buenos Aires na Era do Amor Virtual. Direção de Gustavo Taretto. Argentina: Rizoma Films, 2011. 95 minutos.

NA NATUREZA Selvagem. Direção de Sean Penn. Estados Unidos: Paramount Vantage, 2007. 148 minutos.

NASHVILLE. Direção de Robert Altman. Estados Unidos: ABC Motion Picture, 1975. 160 minutos.

NOIVE Neurótico, Noiva Nervosa. Direção de Woody Allen. Estados Unidos: RollinsJoffe Productions, 1977.93 minutos.

O ARTISTA. Direção de Michel Hazanavicius. França: Studio 37 e Le Petite Reine, 2011. 100 minutos.

O ECLIPSE. Direção de Michelangelo Antonioni. Itália: Cineriz, 1962. 126 minutos.

O ILUMINADO. Direção de Stanley Kubrick. Estados Unidos e Reino Unido: Hawk Films, 1980. 146 minutos.

O MESTRE. Direção de Paul Thomas Anderson. Estados Unidos: Ghoulardi Film Company. 2012. 137 minutos. 
O PERIGOSO Adeus. Direção de Robert Altman. Estados Unidos: Lion's Gate Films, 1973. 112 minutos.

O SILÊNCIO. Direção de Ingmar Bergman. Suécia: Svensk Filmindustri, 1963. 105 minutos.

OS BONS Companheiros. Direção de Martin Scorsese. Estados Unidos: Warner Bros., 1990. 145 minutos.

PARIS, Texas. Direção de Wim Wenders. Alemanha e França: Road Movies Filmproduktion, 1984. 147 minutos.

POPEYE. Direção de Robert Altman. Estados Unidos: Paramount Pictures e Walt Disney Productions, 1980. 114 minutos.

PSICOSE. Direção de Alfred Hitchcock. Estados Unidos: Shamley Productions, 1960. 109 minutos.

PULP Fiction - Tempos de Violência. Direção de Quentin Tarantino. Estados Unidos: A Band Apart e Jersey Films, 1994. 154 minutos.

SANGUE Negro. Direção de Paul Thomas Anderson. Estados Unidos: Ghoulardi Film Company, 2007. 158 minutos.

SHORT Cuts - Cenas da Vida. Direção de Robert Altman. Estados Unidos: Fine Line Features, 1993. 188 minutos.

SILÊNCIO. Direção de Martin Scorsese. Estados Unidos, Taiwan, México, Reino Unido, Itália e Japão, 2016. 161 minutos.

SUPERMAN: O Filme. Direção de Richard Donner. Reino Unido, Suíça, Panamá e Estados Unidos: Film Export A.G., Dovemead Limited e International Film Productions, 1978. 143 minutos.

TAXI Driver. Direção de Martin Scorsese. Estados Unidos: Columbia Pictures, 1976. 113 minutos.

TITANIC. Direção de James Cameron. Estados Unidos: Twentieth Century Fox e Paramount Pictures, 1997. 195 minutos. 
TOURO Indomável. Direção de Martin Scorsese. Estados Unidos: Chartoff-Winkler Productions, 1980. 149 minutos.

TRAMA Fantasma. Direção de Paul Thomas Anderson. Estados Unidos: Ghoulardi Film Company, 2017. 130 minutos.

TUBARÃO. Direção de Steven Spielberg. Estados Unidos: Zanuck/Brown Productions, 1975. 124 minutos.

UM LUGAR Silencioso. Direção de John Krasinski. Estados Unidos: Platinum Dunes, 2018. 90 minutos.

VícıO Inerente. Direção de Paul Thomas Anderson. Estados Unidos: Ghoulardi Film Company, 2014. 149 minutos. 